\title{
O regime económico das cooperativas à luz do novo Código Cooperativo português
}

The financial structure regime of cooperatives in the new portuguese Cooperative Code

\author{
Deolinda A. Meira ${ }^{1}$ \\ Instituto Politécnico do Porto/ISCAP/CECEJ (Portugal)
}

Sumário: 1. Introdução. 2. O contexto da reforma. 3. As alterações ao regime económico das cooperativas. 3.1. As alterações ao regime do capital social. 3.1.1. A abertura do capital social cooperativo a investidores externos. 3.1.2. A obrigatoriedade de um capital social mínimo. 3.1.3. Alterações no regime do capital social mínimo. 3.1.4. O reconhecimento expresso da variabilidade do capital social e a introdução de mecanismos de atenuação dos seus efeitos. 3.1.5. Alterações quanto ao tipo e natureza das contribuições para o capital social. 3.2. Clarificação do regime de transmissão dos títulos de capital. 3.3. Remuneração dos títulos de capital. 3.4. Reembolso dos títulos de capital. 3.5. Reconhecimento expresso da possibilidade de recurso a outras formas de financiamento. 3.6. Consagração expressa do regime do aumento da capital social. 3.7. Maior clarificação em matéria de responsabilidade. 3.8. Novas soluções normativas quanto às reservas cooperativas. 3.8.1. Reserva legal. 3.8.2. Reserva de educação e formação cooperativas. 3.8.3. A irrepartibilidade das reservas (obrigatórias ou outras). 3.9. O regime jurídico da determinação e distribuição de resultados: uma oportunidade perdida. 4. Conclusões. 5. Bibliografia.

Summary: 1. Introduction. 2. The context of the reform. 3. Modifications to the cooperative financial structure regime. 3.1. Amendments to the share capital regime. 3.1.1. The opening of the cooperative share capital to investor members. 3.1.2. The requirement of a minimum share capital. 3.1.3. Amendments in the minimum share capital regime. 3.1.4. The express recognition of the variability of the share capital and the introduction of attenuation mechanisms of its effects. 3.1.5. Amendments in the type and nature of contributions to the

1 Professora Adjunta do Instituto Politécnico do Porto / ISCAP / CECEJ. Correio eletrónico: meira@iscap.ipp.pt. Correio postal: Instituto Superior de Contabilidade e Administração do Porto, Rua de Jaime Lopes de Amorim, 4465-004 S. Mamede de Infesta, PORTU̧GAL. 
share capital. 3.2. Clarification of the transfer of member shares regime. 3.3. Remuneration of the contributions to the share capital. 3.4. Reimbursement of the contributions to the share capital. 3.5. Explicit recognition of the possibility of using other financing forms. 3.6. Explicit recognition of the regime of the share capital increase. 3.7. Further clarification regarding liability. 3.8. New legislative solutions for cooperative reserves. 3.8.1. The legal reserve. 3.8.2. The reserve for cooperative education and training. 3.8.3. The indivisibility of the reserves (mandatory or otherwise). 3.9. The legal regime for the determination and allocation of revenues: a lost opportunity. 4. Conclusions. 5. Bibliography.

Resumo: O presente estudo analisa os principais vetores de evolução do regime económico das cooperativas, após a reforma do Código Cooperativo português. De modo a assegurar a sustentabilidade da cooperativa, fornecendo-lhe mecanismos adequados para ser eficiente no mercado, a reforma introduziu a figura dos membros investidores, reduziu o capital social mínimo, alargou o elenco dos limites estatutários ao exercício do direito ao reembolso, fortaleceu a função de garantia do capital social e da reserva legal. Na modernização do regime económico, o legislador não abdicou da preservação da identidade cooperativa, continuando a reconhecer a variabilidade do capital social, a irrepartibilidade das reservas obrigatórias e das reservas constituídas com resultados provenientes de operações com terceiros, e as especificidades da reserva de educação e formação cooperativas. No entanto, a abordagem legal da problemática da determinação e distribuição de resultados revelou-se insuficiente.

Palavras chave: cooperativa, regime económico, capital social, reservas, excedente, membro investidor.

Abstract: This study analyses the major points of development of the cooperative financial structure regime after the reform of the Portuguese Cooperative Code. In order to ensure the sustainability of the cooperative, providing it with appropriate mechanisms to be efficient on the market, the reform introduced the figure of investor members, reduced the amount of the minimum share capital, extended the list of statutory limits on exercising the right to reimbursement, strengthened the guarantee function of the share capital and of the legal reserve. In the modernization of the cooperative financial structure regime the legislator did not abdicate of the preservation of the cooperative identity, continuing to recognize the variability of the share capital, the indivisibility of the mandatory reserves and of the reserves established with results from transactions with non-members, and the specificities of the reserve for cooperative education and training. Nevertheless, the legal approach to the problem of determination and allocation of revenues from cooperative economic activity is considered to be insufficient.

Key words: cooperative, financial structure regime, share capital, reserves, cooperative surplus, investor member. 


\section{Introdução}

O presente estudo tem em vista refletir sobre os principais vetores de evolução do regime económico das cooperativas após a reforma do Código Cooperativo português (CCoop), levada a cabo pela Lei n. ${ }^{\circ} 119 / 2015$, de 31 de agosto 2 .

Antes de olharmos para as questões centrais do regime económico das cooperativas que foram objeto de disposições reformadoras, cumpre referir que as cooperativas apresentam um regime económico com muitas especificidades. Estas especificidades estão presentes na própria definição de cooperativa que consta do art. 2. ${ }^{\circ}$ do CCoop, que a reforma manteve inalterada, e nos termos da qual são cooperativas as «pessoas coletivas autónomas, de livre constituição, de capital e composição variáveis, que, através da cooperação e entreajuda dos seus membros, com obediência aos princípios cooperativos, visam, sem fins lucrativos, a satisfação das necessidades e aspirações económicas, sociais ou culturais daqueles».

Esta definição tem, implícitos, dois elementos: um elemento positivo - o fim mutualístico - e um elemento negativo - a ausência de um fim lucrativo. Assim, o objeto social da cooperativa surge intimamente ligado à sua vocação mutualista, pelo que toda a atividade da cooperativa visa a promoção dos interesses dos cooperadores, ou seja, a satisfação das suas necessidades económicas, sociais e culturais.

De facto, diversamente de uma sociedade comercial, as cooperativas desenvolvem uma atividade económica que prossegue um fim mutualístico e não lucrativo. Contudo, este fim mutualístico não implica que as cooperativas desenvolvam atividade apenas com os seus membros, podendo também realizar operações com terceiros, o que terá, naturalmente, reflexos na sua estrutura financeira.

Acresce que, no desenvolvimento do seu objeto social, as cooperativas devem observar os princípios cooperativos, que aparecem enunciados no art. $3 .^{\circ}$ do CCoop: adesão voluntária e livre; gestão democrá-

2 A primeira lei cooperativa portuguesa foi a Lei Basilar do Cooperativismo (Lei de 2 de julho de 1867). Em 1888, as cooperativas passaram a ser regidas pelo Código Comercial de Veiga Beirão. Em 1980, entrou em vigor um Código Cooperativo (Decreto-Lei n. ${ }^{\circ} 454 / 80$, de 9 de outubro). Em 1997, entrou em vigor um novo Código (Lei n. ${ }^{\circ}$ 51/96), que foi, entretanto, alterado: pelo Decreto-Lei n. ${ }^{\circ} 343 / 98$, de 6 de novembro; pelo Decreto-Lei n. ${ }^{\circ} 131 / 99$, de 21 de abril; pelo Decreto-Lei n. ${ }^{\circ}$ 108/2001, de 6 de abril; pelo Decreto-Lei n. ${ }^{\circ}$ 204/2004, de 19 de agosto; e pelo Decreto-Lei n. ${ }^{\circ}$ 76A/2006, de 29 de março. Em 30 de setembro de 2015, entrou em vigor o atual Código Cooperativo (CCoop). 
tica pelos membros; participação económica dos membros; autonomia e independência; educação, formação e informação; intercooperação; e interesse pela comunidade.

Esta exposição terá, por isso, em conta que o regime económico das cooperativas se baseia numa lógica própria que resulta das características específicas do seu objeto social e da necessária obediência aos princípios cooperativos.

Contudo, é por todos reconhecido que a cooperativa carece de um regime económico que the assegure a sua sustentabilidade e que Ihe forneça os mecanismos necessários para ser eficiente no mercado. Neste sentido, enquanto operador económico, a cooperativa pode utilizar títulos de capital, dotar-se de reservas, emitir títulos de investimento, obrigações e outros instrumentos financeiros, desde que compatíveis com os princípios cooperativos.

Nas linhas que se seguem faremos, então, uma análise crítico-reflexiva das questões centrais do regime económico das cooperativas que foram objeto de alteração no novo Código Cooperativo português. Tal análise não dispensa que, num primeiro momento, se aborde, ainda que de forma breve, o contexto da reforma.

\section{O contexto da reforma}

É consensual na doutrina que a legislação cooperativa tem um importante papel no desenvolvimento do setor cooperativo ${ }^{3}$. A estabilidade do regime jurídico, que é em si mesma um bem, não deve ser encarada de forma absoluta, sob pena de conduzir a uma cristalização das leis, com os inevitáveis prejuízos para o setor cooperativo e para a economia em geral 4 .

Na reforma esteve sempre presente a preocupação em preservar a identidade cooperativa perante a sedução exercida pelas sociedades comerciais e que, em alguns ordenamentos jurídicos, tem conduzido a

$3 \mathrm{~V}$., por todos, Antonio Fici, "The essential role of cooperative law», The Dovenschmidt Quartely, International Review on Transitions in Corporate Life, Law and Governance, n. ${ }^{\circ} 04$ (2014): 147-158.

4 Para o elenco dos problemas que deveriam ser objeto de revisão no Código Cooperativo português, em matéria de governação e regime económico, v. Deolinda A. Meira e Maria Elisabete Ramos, Governação e regime económico das cooperativas. Estado da arte e linhas de reforma (Porto: Vida Económica, 2014), passim. 
uma excessiva liberalização do regime jurídico cooperativo ${ }^{5 / 6}$. Contudo, - legislador não se podia alhear da concorrência entre ordenamentos jurídicos, das reformas legislativas ocorridas em países que nos são jurídica e culturalmente próximos, das necessidades de redução de custos de contexto jurídico, de manutenção da atratividade das cooperativas e de reforço da sua sustentabilidade?.

O início formal da reforma legislativa aconteceu com a aprovação da Lei de Bases da Economia Social $(L B E S)^{8}$, a qual impulsionou a revisão dos diplomas enquadradores das diferentes entidades pertencentes ao setor da Economia Social. Para tanto, foi criado o «Grupo de TrabaIho para a Revisão da Legislação da Economia Social», constituído na sequência do Plenário do "Conselho Nacional da Economia Social» de 1 de abril de 2013 - e, no seu âmbito, foi criada a «Comissão Redatorial para a Revisão da Legislação Cooperativa».

Como resultado dos trabalhos da «Comissão Redatorial para a Revisão da Legislação Cooperativa», que duraram sensivelmente um ano, foi apresentado um Anteprojeto? .

As principais alterações propostas no referido Anteprojeto foram:

a) a diminuição do número mínimo de cooperadores, de cinco para três, nas cooperativas de primeiro grau;

b) a ampliação da autonomia estatutária, mediante a tipificação de três modelos de estrutura de administração e fiscalização

5 Alertando para o fenómeno da societarização das cooperativas por via legislativa e os seus riscos, v. Hagen Henrÿ, Guidelines for Cooperative Legislation (Genebra: International Labour Office, 2012), 20 e ss.

${ }^{6}$ Lugar de destaque, como reação a esta excessiva liberalização e à consequente crise de identidade cooperativa, é devido ao primeiro projeto desenvolvido pelo SGECOL (Study Group on European Cooperative Law), designado «Principles of European Cooperative Law (PECOL). Sobre este projeto, v. Isabel-Gemma Fajardo García et al., «El Nuevo grupo de studio en derecho cooperative europeo y el Proyecto «Los principios del derecho cooperative europeo», CIRIEC-España, Revista Jurídica de Economía Social y Cooperativa, n. ${ }^{\circ} 24$ (2013): 331-347. Em 9 de junho de 2015, foi feita uma apresentação pública do projeto, em Bruxelas. V. Study Group on European Cooperative Law (SGECOL), Draft Principles of European Cooperative Law (draft PECOL), May 2015, http://www. euricse.eu/wp-content/uploads/2015/04/PECOL-May-2015.pdf (última consulta em 29 de maio de 2016).

7 V., neste sentido, Meira e Ramos, Governação..., 9 e ss..

8 Lei n. ${ }^{\circ}$ 30/2013, de 8 de maio. Sobre a Lei de Bases da Economia Social portuguesa, v. Deolinda A. Meira, "A Lei de Bases da Economia Social Portuguesa: do projeto ao texto final», CIRIEC-España, Revista Jurídica de Economía Social y Cooperativa, n. ${ }^{\circ} 24$ (2013): 21-52.

9 https://docs.google.com/file/d/OB1mJcaVP82BkSXhRb3ZjWEtLRzQ/edit (última consulta em 29 maio de 2016). 
da cooperativa - conselho de administração e conselho fiscal; conselho de administração, comissão de auditoria e revisor oficial de contas; conselho de administração executivo, conselho geral e de supervisão, e revisor oficial de contas;

c) a reformulação e clarificação dos deveres dos administradores da cooperativa;

d) a revisão do regime da responsabilidade civil pela administração e fiscalização da cooperativa;

e) a revisão e ressistematização do regime económico das cooperativas, agregando as normas sobre este regime em capítulo próprio;

f) a redução do capital social mínimo;

g) a clarificação dos regimes de responsabilidade dos cooperadores pelas dívidas da cooperativa, e da posição do património da cooperativa perante os seus credores e perante os credores particulares do cooperador;

h) a clarificação do regime do aumento do capital social;

i) a imposição de limites à variabilidade do capital social e ao direito ao reembolso;

j) a clarificação do regime jurídico das entradas para o capital social e do regime de transmissão dos títulos de capital;

l) a consagração de novas soluções normativas quanto às reservas.

Concluídos, em 2014, os trabalhos da «Comissão Redatorial para Revisão da Legislação Cooperativa», as Confederações Cooperativas portuguesas CONFECOOP e CONFAGRI, que integravam a referida Comissão, concordaram que a reforma dos preceitos do Código Cooperativo deveria ocorrer por iniciativa legislativa da Assembleia da República. Neste sentido, em fevereiro de 2015, o Ministro da Solidariedade, Emprego e Segurança Social remeteu à Assembleia da República um documento com os contributos da «Comissão Redatorial para a Revisão da Legislação Cooperativa», solicitando a sua distribuição pelos grupos parlamentares com assento na Assembleia da República, de modo a ser iniciado o processo legislativo.

Na sequência da remissão deste documento à Assembleia da República, foi apresentado um outro projeto, o Projeto de Lei n. ${ }^{\circ} 898 / X I I$, que procedeu à alteração do Código Cooperativo de 1996, não totalmente coincidente com o Anteprojeto elaborado pela «Comissão Redatorial para a Revisão da Legislação Cooperativa», dado que consagrava o voto plural e os membros investidores, matérias sobre as quais o Anteprojeto não tomava posição. 
Em sede de Comissão Parlamentar, e após um conjunto de audições, foram introduzidas alterações nas normas que acolhiam as figuras do voto plural e dos membros investidores, de forma a torná-las compatíveis com os princípios cooperativos e, em 23 de julho, foi aprovada a nova versão do Código Cooperativo, a qual foi publicada no Diário da República do dia 31 de agosto de $2015^{10}$.

\section{As alterações ao regime económico das cooperativas}

Olhemos, agora, para as questões centrais do regime económico das cooperativas que foram objeto de disposições reformadoras e para as novidades legislativas que têm implicações nesse regime, com particular destaque para a figura dos membros investidores.

\subsection{As alterações ao regime do capital social}

\subsubsection{A ABERTURA DO CAPITAL SOCIAL COOPERATIVO A INVESTIDORES EXTERNOS}

O novo CCoop prevê, de forma inovadora, a figura dos membros investidores. Estes são membros de natureza contingente ou adjetiva, cuja presença não é necessária para a válida existência da cooperativa, e que se caracterizam por reduzir o seu compromisso obrigacional à mera entrada para o capital social. São, portanto, membros que colaboram na consecução do fim social através de uma contribuição financeira para a cooperativa, não participando na actividade cooperativizada ${ }^{11 / 12}$.

10 Diploma disponível em http://www.cases.pt/0_content/cooperativas/legislacao/ Lei_2015_119_AprovaCód_Cooperativo.pdf.

11 Sobre o conceito de atividade cooperativizada, v. Carlos Vargas Vasserot, La actividad cooperativizada y las relaciones de la Cooperativa con sus sócios y con terceros (Navarra: Editorial Thomson Aranzadi, 2006): 67.

12 No ordenamento espanhol, a Ley Estatal de Cooperativas - Ley 27/1999, de 16 de julio prevê o chamado asociado (arts. $39 .^{\circ}$ a $41 .^{\circ}$ ) e o socio colaborador (art. $14 .{ }^{\circ}$ ). O ordenamento italiano prevê a figura do sócio sovventore (art. $4 .^{\circ}$ da Legge 59/1992). No ordenamento francês está prevista a figura do associé non coopérateur [art. $3 .^{\circ}$ bis da Loi n. ${ }^{\circ}$ 47-1775 - Statut de la Coopération (Portant statut de la coopération)]. O n. ${ }^{\circ} 1$ do art. $14 .^{\circ}$ do Estatuto da Sociedade Cooperativa Europeia (ESCE) - Regulamento (CE) n. 1 435/2003, do Conselho, de 22 de julho de 2003, também acolhe a figura do "sócio de capital», dispondo que "quando a legislação do Estado-Membro da sede da SCE o permita, os estatutos podem prever que pessoas não vocacionadas para utilizar ou fornecer os bens e serviços da SCE possam ser admitidos na qualidade de membros investidores (não utilizadores). Nesse caso, a aquisição da qualidade de membro estará sujeita a aprovação da assembleia geral ou de qualquer órgão mandatado para o fazer pela assembleia geral ou pelos estatutos». 
Estes membros investidores poderão proporcionar à cooperativa a obtenção de meios de financiamento em melhores condições do que os oferecidos pelo mercado, quando não sejam suficientes os recursos trazidos pelos membros cooperadores ${ }^{13}$.

A presença dos membros investidores põe em causa a tradicional configuração da cooperativa como contrato plurilateral com unicidade de fim, já que aqueles são portadores de interesses estranhos à mutualidade, visando, exclusivamente, a remuneração das suas entradas de capital e não participando no intercâmbio mutualista.

É claro que, em nome da necessária conciliação da função mutualista com as exigências de financiamento da cooperativa, se deverá limitar quantitativamente o fim lucrativo, o qual apresentará sempre um carácter secundário face ao prevalecente fim mutualista, devendo ser os membros cooperadores os membros de referência da cooperativa, aos quais se atribuirá a maioria dos votos de forma a assegurar-lhes a administração e fiscalização da mesma e impossibilitar o controlo capitalista da cooperativa. Neste sentido, a doutrina considera que, quando na cooperativa se admitam membros investidores, quer a sua admissão, quer a sua remuneração, deverão ser decididas pelos membros cooperadores e, caso aqueles participem nos órgãos sociais, deverá garantir-se que, em qualquer destes órgãos, o controlo dos mesmos estará em poder dos membros cooperadores ${ }^{14}$.

13 V. María Luisa Llobregat Hurtado, "Régimen económico de las sociedades cooperativas en el marco de la nueva Ley General de Cooperativas de 16 de julio de 1999 (BOE de 17 de julio)», RdS, n. 13 (1999): 228; e Giovanni Capo, "Le società cooperative e lo scopo mutualistico», em Società Cooperative e Mutue Assicuratrici, ed. por Amedeo Bassi (Torino: UTET, 1999), 37-38. María del Carmen Pastor Sempere, Los recursos propios en las sociedades cooperativas (Madrid: Editoriales de Derecho Reunidas, SA, 2002), 115, fala, a este propósito, de uma espécie de "cooperativa em comandita», dada a contraposição de duas categorias de membros que operam sob um esquema híbrido de organização, no âmbito de uma relação jurídica societária unitária - tal como acontece nas sociedades comerciais em comandita, nas quais deparamos com dois tipos de sócios: sócios comanditados e sócios comanditários. Conclui a autora que esta nova cooperativa surgirá, assim, como uma espécie de "modelo hermafrodita», em sentido tipológico, já que entre o sócio cooperador e o sócio de capital existe uma antinomia claríssima quanto ao fim prosseguido (fim mutualista e fim lucrativo) e, consequentemente, de disciplina. V., igualmente, Chapter 2-Section 2.4, Draft Principles of European Cooperative Law ..., 48.

14 A este propósito, Massimo Bione, "Le categorie dei soci finanziatori», em La Società Cooperative: aspetti civilistici e tributari, ed. por Giorgio Schiano di Pepe e Fabio Graziano, II Diritto Tributario, coord. por Antonio Uckmar e Victor Uckmar, Serie I, Vol. LXXXIV (Padova: CEDAM, 1997), 28 e ss., fala da sujeição dos «sócios de capital» a um «vínculo de minoria», traduzido em limitações quantitativas quanto ao direito de voto e à presença nos órgãos de administração da cooperativa. Sensível a es- 
Neste sentido, em nome da preservação dos princípios cooperativos, com particular destaque para o princípio da gestão democrática e o princípio da autonomia e independência, o legislador sujeitou esta nova figura a apertados limites imperativos.

Deste modo, a admissão de membros investidores resultará sempre de uma decisão dos cooperadores. Assim, no momento da constituição da cooperativa, os estatutos deverão necessariamente fixar as «condições e limites da existência de membros investidores quando os houver» [al. f) do n. ${ }^{\circ} 1$ do art. $16 .^{\circ}$ do CCoop]. No n. ${ }^{\circ} 1$ do art. $20 .^{\circ}$ determina-se que «os estatutos podem prever a admissão de membros investidores». Isto significa que os membros investidores não poderão ser membros fundadores da cooperativa.

Para além de previsão estatutária, a admissão de membros investidores ainda estará dependente de proposta do órgão de administração a ser submetida a aprovação da assembleia geral (n. os 3 e 4 do art. 20 . $^{\circ}$ do (Coop). Tal significa que, se os estatutos nada disserem sobre a admissão de membros investidores, não poderá a assembleia geral deliberar no sentido de os admitir. Uma vez admitidos, os membros investidores poderão participar, ainda que limitadamente, nas decisões da cooperativa, não podendo representar, em caso algum, mais de $25 \%$ do número de elementos efetivos que integrem o órgão (de administração ou de fiscalização) para que são eleitos (n. 8 do art. $29 .^{\circ}$ do (Coop) $)^{15}$.

tas preocupações doutrinais, a Ley Estatal de Cooperativas - Ley 27/1999, de 16 de julio (art. 14..$^{\circ}$ ) estabeleceu que as entradas realizadas pelos sócios colaboradores não poderão exceder $45 \%$ do total do capital social, nem o conjunto dos votos a eles correspondentes, somados entre si, poderão superar $30 \%$ dos votos nos órgãos sociais da cooperativa. Por sua vez, o Codice Civile italiano, consagra um conjunto de regras com vista a evitar que os sócios sovventori assumam o controlo da gestão da cooperativa: os votos atribuídos aos sócios sovventori não poderão ser superiores a um terço dos votos atribuídos a todos os outros sócios (art. 2 526, parágrafo 2. ${ }^{\circ}$ ); os sócios sovventori poderão ser nomeados administradores, mas a maioria dos administradores deverá ser constituída por cooperadores. Quanto aos direitos dos sócios sovventori e seus limites, v. Andrea Zopini, Daniela Boggiali e Antonio Ruotolo, "Coordinamento tra la disciplina dei soci sovventori e le norme sui soci finanziatori», em Studi e materiali in tema di riforma delle Società Cooperative (Milano: Consiglio Nazionale del Notariato, Guiffrè Editore, 2005), 621-631. No ordenamento francês, o art. 19. tervicies do Statut de la Coopération consagrou um limite para todos os instrumentos financeiros, estabelecendo que "os certificados cooperativos de investimento, os certificados cooperativos dos associados e as participações de interesse prioritário não poderão representar, no seu conjunto, mais do que $50 \%$ do capital». V., neste sentido, David Hiez, Coopératives. Création, Organisation, Fonctionnement (Paris: Éditions Delmas, 2013), 118 e ss.

15 Considerando que os membros investidores não deveriam integrar os órgãos de administração e de fiscalização da cooperativa, v. Meira e Ramos, Governação..., 54. 
Em matéria de voto, no silêncio dos estatutos, vigorará a regra «um membro, um voto», mas o novo Código admite a possibilidade de os estatutos consagrarem, respeitados que sejam determinados limites legais imperativos, o voto plural nas cooperativas de primeiro grau ( $\mathrm{n} .{ }^{\circ} 1$ do art. $41 .^{\circ}$ do (Coop), o qual poderá ser atribuído a cooperadores ou a membros investidores. Sendo atribuído a membros investidores sê-loá em função da sua participação no capital social.

O novo Código Cooperativo remete para os estatutos a definição das condições e critérios de que dependerá a atribuição de voto plural aos membros investidores ( $\mathrm{n} .^{\circ} 5$ do art. $41 .^{\circ}$ do CCoop).

Todavia, o Código Cooperativo consagra, em normas legais imperativas, limites quanto à atribuição do voto plural (art. $41 .^{\circ}$ do CCoop):

a) limites quanto à dimensão da cooperativa — em cooperativas com menos de 20 cooperadores está proibido o voto plural;

b) limites quanto a determinados ramos - o voto plural está proibido nas cooperativas de produção operária, de artesanato, de pescas, de consumo e de solidariedade social;

c) limites quanto ao número de votos a atribuir a cada membro investidor - três, em cooperativas até 50 cooperadores, e cinco, em caso de cooperativas com mais de 50 cooperadores;

d) limites quanto às matérias objeto de deliberação pela assembleia geral - em deliberações previstas nas alíneas g), h), i) e j) do art. $38 .^{\circ}$ do CCoop ${ }^{16}$, cada cooperador / membro investidor dispõe apenas de um voto (funcionará, pois, exclusivamente, a regra geral constante do n. ${ }^{\circ} 1$ do art. $40 .^{\circ}$ do CCoop, ou seja, «um membro, um voto»);

e) por fim, limites para os membros investidores — os membros investidores não podem, no total, ter direitos de voto superiores a $30 \%$ do total de votos dos cooperadores (n. ${ }^{\circ} 7$ do art. $41 .^{\circ}$ do (Coop) $)^{17}$.

16 Trata-se de matérias para as quais o legislador exige uma maioria qualificada de, pelo menos, dois terços dos votos expressos ( $n .^{\circ} 1$ do art. $40 .^{\circ}$ do CCoop), por se tratar de matérias relativas a questões fundamentais da vida da cooperativa e não simples matérias de gestão corrente. Tais matérias respeitam à alteração dos estatutos, à aprovação e alteração dos regulamentos internos, à aprovação da fusão, cisão, dissolução voluntária da cooperativa, bem como à aprovação da filiação da cooperativa em uniões, federações e confederações. Sobre a noção de «fundamental decisions» na cooperativa, v. Chapter 2-Section 2.4, Draft Principles of European Cooperative Law..., 43.

17 V. Deolinda A. Meira e Maria Elisabete Ramos, «Os princípios cooperativos no contexto da reforma do Código Cooperativo português», CIRIEC-España, Revista Jurídica de Economía Social y Cooperativa, Monográfico, n. ${ }^{\circ} 27$ (2015): 401-427. 
A admissão de membros investidores poderá ser feita através da subscrição de títulos de capital ou de títulos de investimento convertíveis em títulos de capital ( $n .^{\circ} 2$ do art. $16 .^{\circ}$ do CCoop), sendo que o legislador não estabeleceu montantes mínimos ou máximos para as contribuições dos membros investidores.

Os únicos limites estabelecidos pelo CCoop reportam-se aos direitos políticos dos membros investidores (acima referidos): voto e elegibilidade para os órgãos sociais.

Diversamente, em outros ordenamentos jurídicos colocam-se limites máximos quanto à participação dos membros investidores no capital social das cooperativas. Destaque-se, neste sentido, o art. $14 .^{\circ} \mathrm{da}$ Ley Estatal de Cooperativas espanhola, nos termos da qual as contribuições dos membros investidores não poderão representar mais do que $45 \%$ do capital social da cooperativa.

\subsubsection{A OBRIGATORIEDADE DE UM CAPITAL SOCIAL MÍNIMO}

A regra geral - que vinha de trás e que se mantém - é a de que não será possível constituir uma cooperativa sem capital social, possibilidade admitida em outros ordenamentos jurídicos ${ }^{18}$.

Assim, o capital social inicial deverá estar, necessariamente, determinado nos estatutos da cooperativa [al. f) do n. 1 do art. $15 .^{\circ}$ do CCoop]. Acresce que o cooperador só adquire a qualidade de membro mediante a realização de uma entrada para o capital social ${ }^{19}$, entrada que não poderá ser inferior a três títulos de capital (art. 83. ${ }^{\circ}$ do CCoop). Dado que o CCoop admitiu a possibilidade de existência de membros investidores na cooperativa, dever-se-ia ter especificado a possibilidade de estas entradas poderem ser diferenciadas consoante o tipo de membros, designadamente se é cooperador ou membro investidor. Ainda que esta diferenciação possa estar prevista estatutariamente [al f) do n. ${ }^{\circ} 1$ do art. $16 .^{\circ}$ do CCoop], entendemos que teria sido pertinente a sua previsão expressa, de forma a vincar os distintos estatutos das duas categorias de membros.

18 Aponte-se, neste sentido, o ordenamento britânico [lan Snaith, «United Kingdom», em International Handbook of Cooperative Law, ed. por Dante Cracogna, Antonio Fici e Hagen Henrÿ (Heidelberg, Springer, 2013), 745-748], o norte-americano [Barbara Czachorska-Jones, Jay Gary Finkelstein e Bahareh Samsami, «United States», em International Handbook of Cooperative Law, 769-770] e o brasileiro (Adriano Campos Alves, «Brazil», em International Handbook of Cooperative Law, 279-281). No mesmo sentido, v. Chapter 3-Section 3.2, Draft Principles of European Cooperative Law..., 66.

19 O capital social é representado por títulos de capital, que são nominativos e que têm um valor nominal de cinco euros ou um seu múltiplo (art. 82. ${ }^{\circ}$ do CCoop). 
No caso dos cooperadores, a entrada para o capital social tem um caráter instrumental face à sua obrigação de participação na atividade da cooperativa, não sendo em função dela que serão definidos os seus direitos e deveres.

A cooperativa tem, a título principal, um escopo mutualístico e, por isso, para desenvolver o seu projeto empresarial, necessita - mais do que das entradas para o capital social - da participação dos cooperadores na atividade que constitui o seu objeto social. De facto, da definição de cooperativa constante do art. $2{ }^{\circ}$ do CCoop, resulta a absoluta instrumentalidade da cooperativa face aos seus membros. Tal significa que a cooperativa é um instrumento de satisfação das necessidades individuais dos cooperadores que no seio dela, e através dela, cooperam.

O que verdadeiramente identifica a cooperativa é a própria ausência de um escopo autónomo face aos interesses dos cooperadores. Nas cooperativas, constitui requisito sine qua non o envolvimento direto e ativo dos seus membros na própria atividade que a cooperativa desenvolve [al. c) do n. ${ }^{\circ} 2$ do art. $22 .^{\circ}$ do CCoop], ou seja, no cumprimento do seu objeto social. Assim, o cooperador, diversamente do membro investidor, não estará apenas sujeitado à obrigação de entrada para o capital social da cooperativa, mas também e sobretudo à obrigação de participar na atividade da mesma, entregando bens ou produtos à cooperativa (como é o caso de uma cooperativa agrícola); produzindo bens ou prestando serviços no seio da cooperativa (como é o caso das cooperativas de trabalho); ou pagando à cooperativa pelos bens ou serviços que recebem da mesma (como acontece nas cooperativas de consumo ou nas cooperativas de habitação). A este conjunto de fatores trazidos pelos cooperadores para a cooperativa, chama a doutrina massa de gestão económica ou capital mutualístico ${ }^{20}$.

Deste modo, a entrada para o capital social é uma condição necessária, mas nunca suficiente para a aquisição da qualidade de cooperador 21 , enquanto que, no caso dos membros investidores, a entrada para o capital social é uma condição suficiente.

\subsubsection{Alterações no Regime do Capital social mínimo}

Na reforma, o legislador sentiu (e bem) necessidade de reduzir o montante do capital social mínimo, baixando-o de 2.500 euros para

20 V., sobre esta noção, Isabel-Gemma Fajardo García, La gestión económica de la cooperativa: responsabilidad de los sócios (Madrid: Tecnos, 1997), 78-103.

21 Neste sentido, v. Deolinda A. Meira, O regime económico das cooperativas no Direito Português: o capital social (Porto: Vida Económica, 2009), 212-220. 
1.500 euros (n. ${ }^{\circ} 2$ do art. $81 .^{\circ}$ do CCoop), podendo a legislação complementar que regula cada um dos ramos fixar um mínimo diferente 22 .

A reforma resolveu algumas das fragilidades que, por comparação com outros ordenamentos jurídicos, o regime jurídico do capital social mínimo apresentava no ordenamento português.

De facto, o Código Cooperativo de 1996 não consagrava a impossibilidade de o reembolso das entradas afetar o capital social mínimo. Inspirado no Estatuto da Sociedade Cooperativa Europeia (ESCE) — que estabeleceu que o prazo durante o qual os sócios terão direito ao reembolso das suas entradas, quando deixam de fazer parte da cooperativa, será suspenso, enquanto esse reembolso implicar a redução do capital subscrito para um montante inferior ao capital social mínimo (n. ${ }^{\circ} 4$ do art. $3 .^{\circ}$ do ESCE) - , o legislador consagra agora, no n. ${ }^{\circ} 3$ do art. $89 .^{\circ}$ do CCoop, que uos estatutos podem prever que, quando num exercício económico o montante dos títulos de capital a reembolsar supere uma determinada percentagem do montante do capital social que neles se estabeleça, o reembolso fique dependente de uma decisão do órgão de administração», devendo essa suspensão ser fundamentada e sujeita a ratificação da assembleia geral (n. ${ }^{\circ} 4$ do art. 89. ${ }^{\circ}$ do CCoop).

Registamos, todavia, que o legislador não resolveu outras fragilidades importantes do regime do capital social.

Por um lado, a redução do capital social para um montante inferior ao capital social mínimo durante um determinado período de tempo, continua a não ser causa de dissolução e posterior liquidação da cooperativa ${ }^{23}$. Efetivamente, o atual CCoop, na linha da versão anterior, continua a não prever, de forma expressa, esta causa de dissolução.

Por outro, não se consagrou a possibilidade de os credores sociais poderem deduzir oposição judicial à redução do capital social para um montante inferior ao capital social mínimo, com fundamento no pre-

22 V. Deolinda A. Meira, "Contributos legislativos para a criação de empresas cooperativas: a livre fixação do capital social», CIRIEC-España, Revista Jurídica de Economía Social y Cooperativa, n. ${ }^{\circ} 26$ (2015): 35-37.

23 Esta é a solução prevista no ordenamento espanhol [v.g. no art. 45.8.d) da Ley Estatal de Cooperativas - Ley 27/1999, de 16 de julio, ainda que o regime seja comum a todas as leis autonómicas de cooperativas, variando apenas o período de tempo a considerar, que pode ir de seis meses a um ano]. Sobre esta solução, v. M. ${ }^{a}$ Ángeles Martín Reyes e Eugenio Olmedo Peralta, «El capital social. Concepto y funciones», em Tratado de Derecho de Cooperativas, Tomo I, dir. Juan Ignacio Peinado Gracia; coord. Trinidad Vásquez Ruano (Valencia: Tirant Lo Blanch, 2013), 535-552. Também é a solução prevista no ordenamento francês [art. 27 bis do Statut de la Coopération (Portant statut de la coopération - Journal officiel du 11 septembre 1947] e no Chapter 3-Section 3.2, Draft Principles of European Cooperative Law..., 66. 
juízo que dela derive para a reclamação dos seus direitos, desde que tenham solicitado à cooperativa a satisfação dos seus créditos ou a prestação de garantia adequada, sem que o seu pedido tenha sido atendido ${ }^{24}$.

\subsubsection{O RECONHECIMENTO EXPRESSO DA VARIABILIDADE DO CAPITAL SOCIAL E A INTRODUÇÃO DE MECANISMOS DE ATENUAÇÃO DOS SEUS EFEITOS}

A variabilidade do capital social continua a ser reconhecida, expressamente, pelo legislador como uma caraterística essencial da identidade cooperativa, integrando a própria definição de cooperativa $\left(n .{ }^{\circ} 1\right.$ do art. $2 .^{\circ}$ e n. 1 do art. $81 .^{\circ}$ do (Coop). Reconhecendo-se aos cooperadores um verdadeiro direito de demissão, tal como resulta do n. ${ }^{\circ} 1$ do art. $24 .^{\circ}$ do CCoop 25 , a consequência será o reembolso da sua entrada de capital. Efetivamente, no n. ${ }^{\circ} 1$ do art. 89. ${ }^{\circ}$ do CCoop dispôsse que «em caso de reembolso dos títulos de capital, o cooperador que se demitir tem direito ao montante dos títulos de capital realizados segundo o seu valor nominal, no prazo estabelecido pelos estatutos ou, supletivamente, no prazo máximo de um ano».

Sendo o capital social variável, tal significa que poderá aumentar por novas entradas de membros cooperadores e investidores, e reduzir-se por reembolso das entradas aos cooperadores que se demitam, sem necessidade de alteração dos estatutos da cooperativa. A principal consequência desta variabilidade consistirá na diminuição da segurança económica e financeira que o capital social poderia representar perante terceiros credores, podendo dificultar o financiamento externo das cooperativas $^{26}$ e, em determinadas situações, conduzi-las a uma situação de subcapitalização.

Tudo isto é agravado pela circunstância de o legislador continuar a permitir que os cooperadores difiram parte das suas entradas em dinheiro para um momento posterior ao da constituição da cooperativa. Efetivamente, a lei estabelece que $10 \%$ do capital a realizar em dinheiro deverá ser efetuado aquando da subscrição. Permite-se, contudo, que os estatutos possam exigir uma entrega superior. Admite-se,

24 Esta é a solução prevista no ordenamento espanhol (v.g. no art. 45.8 da Ley Estatal de Cooperativas - Ley 27/1999, de 16 de julio). Sobre esta solução, v. Martín Reyes e Olmedo Peralta, «El capital social. Concepto y funciones», 540-550.

25 O n. ${ }^{\circ} 1$ do art. 24. ${ }^{\circ}$ do CCoop estabelece que "os cooperadores podem solicitar a sua demissão nas condições estabelecidas nos estatutos ou, no caso de estes serem omissos, no fim de um exercício social, com pré-aviso de 30 dias, sem prejuízo da responsabilidade pelo cumprimento das suas obrigações como membros da cooperativa».

26 Meira, O regime económico das cooperativas..., 103-117. 
desta forma, o diferimento da realização das entradas em dinheiro dos membros cooperadores ${ }^{27}$, cujo valor deverá, no entanto, estar integralmente realizado no prazo máximo de cinco anos $\left(n .^{\circ} 3\right.$ do art. $84 .^{\circ}$ do CCoop). Tal implica que as cooperativas poderão iniciar a sua atividade com muitos créditos sobre os cooperadores, mas sem os meios líquidos que, efetivamente, Ihes permitam exercer a sua atividade.

Assim se explica que o legislador tenha alargado a possibilidade do estabelecimento de limites ao exercício do direito ao reembolso, de modo a conferir maior estabilidade ao capital social cooperativo. Aos mecanismos já previstos no Código Cooperativo de 1996 - «a possibilidade de diferir o reembolso durante um certo período de tempo» (n. 1 do art. 89..$^{\circ}$ do CCoop); "a possibilidade de estabelecer deduções ao direito ao reembolso» ( $\mathrm{n} .^{\circ} 2$ do art. $89 .^{\circ}$ do CCoop); "O estabelecimento de prazos mínimos de permanência e de regras que condicionem a saída a um aviso prévio» (n. ${ }^{\circ} 2$ e 3 do art. $24 .^{\circ}$ do CCoop); "O regime de responsabilidade externa dos cooperadores» (art. $23 .^{\circ}$ e $80 .^{\circ}$ do CCoop); a já referida "fixação de um capital social mínimo» $\left(n .^{\circ} 2\right.$ do art. $81 .^{\circ}$ do (Coop); e o "regime jurídico-legal definido para as reservas, designadamente para as reservas obrigatórias» (art. $96 .^{\circ}$ e ss. do (Coop), de que falaremos mais adiante - acrescenta-se no novo Código a possibilidade de os estatutos poderem prever a já mencionada suspensão do reembolso (n. os 3 e 4 do art. 89. ${ }^{\circ}$ do CCoop).

Mantém-se a proibição de estes mecanismos poderem suprimir o direito de demissão (n. ${ }^{\circ} 3$ do art. $24 .^{\circ}$ do CCoop), permitindo-se apenas que os estatutos limitem tal direito "estabelecendo regras e condições para o seu exercício». Esta é a melhor solução pois respeita o princípio cooperativo da adesão voluntária e livre.

Claro que esta opção legislativa levanta um problema que se prende com a circunstância de, no ordenamento português, não existir um tratamento contabilístico específico e diferenciado para as cooperativas face às sociedades comerciais, pelo que estas estão sujeitas às normas internacionais de contabilidade, designadamente à IAS 32, com o risco de o capital social ser qualificado, contabilisticamente, como um recurso alheio e não como um recurso próprio ${ }^{28}$, porque reembolsável em caso de demissão do cooperador, o que poderá levar a que nos questionemos se o legislador terá refletido suficientemente so-

27 No caso dos membros investidores, não se permite o diferimento das entradas de capital ( $\mathrm{n} .^{\circ} 5$ do art. $84 .^{\circ}$ do CCoop).

28 V. Deolinda A. Meira e Ana Maria Bandeira, "A IAS 32 e os novos critérios de contabilização das entradas para o capital social das cooperativas. Uma análise contabilística e jurídica», Revista de Ciências Empresariais e Jurídicas, n. ${ }^{\circ} 16$ (2010): 145-164. 
bre as consequências desta sua opção. Na verdade, este impedimento de supressão do direito de demissão e o consequente direito de reembolso significam a rejeição da solução adotada no ordenamento espanhol para impedir a classificação do capital social como passivo, a qual acolhe a possibilidade de, mediante cláusula estatuária, se introduzir uma dualidade no capital social das cooperativas, que passa a estar representado por entradas reembolsáveis ou por entradas cujo reembolso possa ser recusado incondicionalmente pelo órgão de administração da cooperativa em caso de demissão do cooperador ${ }^{29}$.

A única medida introduzida no sentido de atenuar os riscos de o capital social ser qualificado, contabilisticamente, como um recurso alheio foi a possibilidade, já amplamente referida, de estatutariamente se prever que o órgão de administração suspenda o reembolso quando num exercício económico o montante dos títulos de capital a reembolsar supere uma determinada percentagem do capital social que neles se estabeleça (n.os 3 e 4 do art. $89 .^{\circ}$ do CCoop). Assim, se essa percentagem for, por exemplo, de $20 \%$, tal significa que $80 \%$ do capital social deverá ser contabilizado como recurso próprio e $20 \%$ como passivo. Convém, no entanto, ter presente que o novo Código obriga a que a decisão de suspensão do reembolso seja fundamentada e sujeita-a a ratificação da assembleia geral. Estes condicionalismos pretendem assegurar que as limitações ao exercício do direito ao reembolso se fundam em razões objetivas, excluindo-se qualquer restrição que radique no mero arbítrio dos dirigentes da cooperativa ou num excesso de valorização relativa dos interesses da cooperativa e, ainda, que tais limitações não ultrapassem um nível, razoável e justo, de proteção da solvência financeira da cooperativa.

\subsubsection{Alterações Quanto ao tipo e natureza das ContribuiçÕes para o CAPITAL SOCIAL}

Em matéria de capital social, registam-se outras significativas diferenças, quanto ao diploma anteriormente vigente, relativamente às contribuições dos cooperadores para o capital social. No Código Cooperativo de 1996, as entradas dos cooperadores podiam consistir em dinheiro, espécie e indústria. No atual Código Cooperativo, a contribuição de trabalho deixa de ser entendida como uma contribuição para o capital social. A razão da exclusão resulta do facto de as contribuições

29 V., sobre esta questão, Carlos Vargas Vasserot, "Aportaciones exigibles o no exigibles: ésa es la cuestión», CIRIEC-España, Revista Jurídica de Economía Social y Cooperativa, $\mathrm{n} .^{\circ} 22$ (2011): 75-119. 
em trabalho não serem computadas no capital social, pelo que não poderão cumprir com a função de garantia que é própria do capital ${ }^{30}$. Contudo, apesar de o trabalho do cooperador-trabalhador não dever ser entendido como uma contribuição para o capital social, tal não obsta ao seu valor enquanto contribuição social. Estamos perante uma prestação laboral, de caraterísticas peculiares, mas que não é capital social.

Procedeu-se, deste modo, a uma maior clarificação quanto ao regime jurídico das entradas, nos seguintes termos:

i) o capital subscrito pode ser realizado em dinheiro, bens ou direitos;

ii) não podem ser emitidos títulos de capital em contrapartida de contribuições de trabalho ou prestação de serviços, sem prejuízo de a legislação aplicável a cada um dos ramos cooperativos poder exigir, para a aquisição da qualidade de cooperador, uma contribuição obrigatória de capital e de trabalho (arts. $84 .^{\circ} \mathrm{e}$ 85..$^{\circ}$ do (Coop).

O diferimento das entradas em dinheiro só será possível desde que o montante dos valores nominais das entradas em dinheiro e em espécie, entregues inicialmente, atinja pelo menos $10 \%$ do valor do capital social.

\subsection{Clarificação do regime de transmissão dos títulos de capital}

Assiste-se, igualmente, a uma maior clarificação do regime de transmissão dos títulos de capital. O n. ${ }^{\circ} 1$ do art. 86. ${ }^{\circ}$ do CCoop dispõe que os títulos de capital só serão transmissíveis mediante autorização do órgão de administração ou, se os estatutos da cooperativa o impuserem, da assembleia geral, sob condição de o adquirente ou o sucessor já serem cooperadores ou, reunindo as condições exigidas, solicitarem a sua admissão. A titularidade dos títulos de capital não é, assim, uma posição separável da qualidade de cooperador. Tal explica que a

30 A função de garantia significa que o capital social se apresenta como um instrumento jurídico destinado à defesa e tutela dos interesses dos credores. Por força desta função de garantia, são proibidas determinadas atribuições de bens aos sócios. Em consequência, tais bens poderão ser usados para satisfazer as dívidas da sociedade. Sobre esta função na cooperativa, v. Deolinda A. Meira, "As insuficiências do regime legal do capital social e das reservas na cooperativa», em / Congresso Direito das Sociedades em Revista (Coimbra: Almedina, 2011), 133 e ss. 
limitação da livre transmissão dos títulos de capital seja a regra geral e não a exceção, impedindo-se a livre transmissibilidade dos títulos de capital a pessoas alheias à cooperativa.

Como novidade, o CCoop passou a prever expressamente, no n. ${ }^{\circ} 2$ daquela disposição, o formalismo e prazos a observar aquando do pedido e da concessão da autorização para a transmissão dos títulos de capital, devendo tal questão ser regulada nos estatutos da cooperativa nos seguintes termos: o cooperador que pretenda transmitir os seus títulos de capital deverá comunicá-lo, por escrito, ao órgão de administração, devendo a recusa ou concessão de autorização ser comunicada ao cooperador no prazo máximo de 60 dias a contar do pedido, sob pena de essa transmissão se tornar válida e eficaz, desde que o transmissário já seja cooperador ou reúna as condições de admissão exigidas. Assegura-se, deste modo, certeza e segurança jurídica em matéria de procedimentos.

Quanto ao modus operandi de transmissão, introduziram-se preceitos mais claros que distinguem entre a transmissão inter vivos e a transmissão mortis causa, e, dentro das transmissões, entre os títulos de capital titulados e os escriturais (trazendo, com as necessárias adaptações, para o corpo da norma o regime do Código dos Valores Mobiliários, para que se remetia no anterior Código Cooperativo).

Assim, nos n.os 3 e 4 do art. 86. ${ }^{\circ}$, consagrou-se que a transmissão inter vivos dos títulos de capital se opera: a) no caso dos titulados, através do endosso do título, assinado pelos transmitente e adquirente, e por quem obriga a cooperativa, sendo averbada no livro de registos respetivo; b) no caso dos escriturais, através do registo na conta do adquirente, sendo averbada no livro de registos respetivo.

Quanto à transmissão mortis causa dos títulos de capital, dispôs-se que a mesma se operará através da apresentação de documento comprovativo da qualidade de herdeiro ou legatário, mediante o qual será averbado em seu nome: a) no caso dos titulados, no respetivo livro de registo, devendo o título ser assinado por quem obriga a cooperativa e pelo herdeiro ou legatário; b) no caso dos escriturais, na conta do adquirente, sendo averbados no livro de registo respetivo. A mensagem legislativa é clara no sentido de que, não sendo admissível a transmissão mortis causa, o herdeiro ou legatário terá direito ao reembolso dos títulos de capital.

O novo Código Cooperativo passou a proibir expressamente, no n. ${ }^{\circ} 6$ do art. 86. ${ }^{\circ}$, que os credores particulares do cooperador possam penhorar, para satisfação dos seus créditos, os títulos de capital de que o cooperador seja titular. Deste modo, a lei privilegia o caráter estritamente pessoal da participação do cooperador na cooperativa e a con- 
sequente necessidade de evitar que, da mesma e em virtude de uma ação executiva, possam vir a fazer parte sujeitos privados dos requisitos requeridos, pela lei ou pelos estatutos, para serem membros da cooperativa. Além disso, visar-se-á evitar que a cooperativa seja colocada em dificuldades económicas por ação dos credores particulares dos cooperadores, o que poderia acontecer se os referidos credores tivessem o direito de exigir à cooperativa a liquidação da participação do cooperador devedor e o pagamento imediato da respetiva importância.

O novo Código não trata da transmissão das participações sociais dos membros investidores, omissão que é criticável. Consideramos que tal transmissão não é livre, estando dependente de autorização do órgão de administração ou, se os estatutos da cooperativa o impuserem, da assembleia geral ${ }^{31}$.

\subsection{Remuneração dos títulos de capital}

A questão da remuneração dos títulos de capital passou a ser objeto de uma norma autónoma (art. $88 .^{\circ}$ do CCoop), na qual se consagra que, mediante cláusula estatutária, poderão ser pagos juros pelos títulos de capital, sendo que o montante global dos juros não poderá ser superior a $30 \%$ dos resultados anuais líquidos.

Esta autonomização permitiu dar um maior destaque a esta particularidade do capital social das cooperativas, traduzindo-a na possibilidade de os cooperadores e de os membros investidores obterem uma remuneração líquida pelo capital subscrito como condição para serem membros, circunstância proibida nas sociedades comerciais ${ }^{32}$. No anterior Código Cooperativo, o regime da remuneração dos títulos de capital aparecia tratado conjuntamente com o regime da distribuição dos excedentes.

31 V., neste sentido, Chapter 3-Section 3.3, Draft Principles of European Cooperative Law..., 67.

$32 \mathrm{O}$ n. 2 do art. $21 .^{\circ}$ do Código das Sociedades Comerciais, em nome do Princípio da intangibilidade do capital social, consagra que «é vedada a cláusula do contrato social que atribua a um sócio juros ou outra quantia certa, em retribuição do seu capital ou indústria». A única retribuição possível serão os lucros, quando os houver e forem distribuídos. A retribuição certa criaria o risco de distribuição pelos sócios de quantias, a título de juros ou outra retribuição, sem que a sociedade tivesse tido lucros, o que violaria diretamente o Princípio da intangibilidade do capital social que carateriza as sociedades comerciais. V., neste sentido, Paulo de Tarso Domingues, "Capital e património sociais. Lucros e reservas», em Estudos de Direito das Sociedades, 12. ${ }^{a}$ edição, ed. por Jorge Manuel Coutinho de Abreu (Coimbra: Almedina, 2015), 171 e ss. 
Mantém-se, assim, o entendimento de que a ausência de um fim lucrativo nas cooperativas não as impede de remunerar, dentro de certos limites, os títulos de capital subscrito pelos cooperadores e, agora também, pelos membros investidores. No caso dos membros cooperadores, a finalidade desta remuneração será a de compensar o esforço que, para os mesmos, representam as contribuições de capital, constituindo, simultaneamente, um incentivo para que os membros cooperadores realizem entradas de capital mais significativas ${ }^{33}$.

Note-se, no entanto, que o ordenamento português, diversamente de outros ordenamentos, não estabelece, concretamente, limites máximos para o juro a pagar aos membros ${ }^{34}$, mas apenas quanto ao montante global dos juros a pagar $(30 \%)^{35}$.

Acresce que o legislador português não estabeleceu qualquer diferenciação quanto à remuneração das entradas dos membros cooperadores e dos membros investidores ${ }^{36}$, não obstante tal diferenciação poder ser estabelecida estatutariamente.

\subsection{Reembolso dos títulos de capital}

Também o direito ao reembolso dos títulos de capital passou a ser objeto de uma norma autónoma (art. 89. do CCoop). No diploma anteriormente vigente, o regime deste direito aparecia previsto na disposição relativa ao direito de demissão, no capítulo relativo aos direitos dos cooperadores. No novo diploma, o direito ao reembolso é trazido para o capítulo relativo ao regime económico, dado o seu impacto na estrutura financeira da cooperativa.

33 V., neste sentido, Pilar Gómez Aparício, «Algunas consideraciones sobre la remuneración del capital social en las sociedades cooperativas», REVESCO, n. ${ }^{\circ} 72,3{ }^{\text {er }}$ Cuatrimestre (2000): 89.

34 Diversamente, no ordenamento espanhol, o art. 48. ${ }^{\circ}$ da Ley Estatal de Cooperativas - Ley 27/1999, de 16 de julio, dispõe que estes juros não poderão ultrapassar mais de 6 pontos acima do juro legal.

35 Para uma análise desenvolvida desta especificidade da cooperativa, v. Deolinda A. Meira, "O regime de distribuição de resultados nas cooperativas de crédito em Portugal. Uma análise crítica», Boletín de la Asociación Internacional de Derecho cooperativo, n. ${ }^{\circ} 49$ (2015): 83-113, doi: 10.18543/baidc-49-2015.

36 Diversamente, no ordenamento italiano, estabeleceu-se que a taxa de remuneração das entradas dos membros investidores (sócio "sovventore») não poderá ser superior a $2 \%$, relativamente à prevista para os membros cooperadores (art. $2514 .^{\circ}$ do Codice Civile). V., neste sentido, Antonio Fici, «Italy», em International Handbook of Cooperative Law, 488-491. 
O direito ao reembolso é uma consequência natural do princípio cooperativo da adesão voluntária e livre e a razão da variabilidade do capital social. Na verdade, o cooperador que se demitir terá direito: ao montante dos títulos de capital realizados, segundo o seu valor nominal (tendo em conta o fim não lucrativo da cooperativa), o qual poderá ser acrescido dos juros a que o cooperador tiver direito relativamente ao último exercício social; à quota-parte dos excedentes e reservas não obrigatórias repartíveis; e deduzido, se for o caso, das perdas que lhe sejam imputáveis, reveladas no balanço do exercício no decurso do qual surgiu o direito ao reembolso.

Este direito ao reembolso poderá ser objeto de limitações, designadamente a possibilidade de diferimento durante um certo período de tempo, consagrado nos estatutos ou, supletivamente, no prazo máximo de um ano. O novo Código Cooperativo acrescentou, às limitações ao direito ao reembolso previstas no diploma anterior - a possibilidade de diferimento durante um certo período de tempo, consagrada nos estatutos ou, supletivamente, no prazo máximo de um ano-, uma outra limitação, acima mencionada, a saber: se os estatutos assim o previrem, o reembolso será suspenso por decisão do órgão de administração caso supere uma determinada percentagem do montante do capital social estabelecido nos estatutos, sendo que esta decisão deverá ser fundamentada e sujeita a ratificação da assembleia geral (n. ${ }^{\circ} 3$ e 4 do art. 89. ${ }^{\circ}$, , como vimos ${ }^{37}$.

\subsection{Reconhecimento expresso da possibilidade de recurso a outras formas de financiamento}

Uma outra novidade da reforma consistiu na introdução de uma norma aberta, com a epígrafe "contribuições que não integram o capital social e outras formas de financiamento» (art. 90. ${ }^{\circ}$ do CCoop).

Mantém-se a possibilidade já prevista na versão anterior do Código de os estatutos da cooperativa poderem exigir a realização de uma joia de admissão, pagável de uma só vez ou em prestações periódicas (n. ${ }^{\circ} 1$ do art. 90. ${ }^{\circ}$. Trata-se de uma contribuição a fundo perdido, sem que o cooperador receba qualquer direito em contrapartida.

De facto, diversamente das entradas para o capital social, o cooperador não recebe qualquer remuneração pela joia. Além disso, na

37 Sobre o direito ao reembolso, v. Rodrigo Viguera Revuelta, El derecho de reembolso en las sociedades cooperativas (Valencia: Tirant Lo Blanch, 2015), 115 e ss.. 
estrutura financeira da cooperativa, a joia ingressa no património da cooperativa e não no capital social, pelo que o cooperador não terá direito a recuperá-la em caso de demissão. Assim, o n. 2 do art. $90 .^{\circ}$ do CCoop dispôs que o montante das joias «reverte para reservas obrigatórias, conforme constar dos estatutos, dentro dos limites da lei». Um mínimo de $5 \%$ do valor das joias reverterá para a reserva legal até que esta "atinja um montante igual ao máximo do capital atingido pela cooperativa» (n. os 2 e 3 do art. $96 .^{\circ}$ do CCoop). O valor remanescente das joias deverá reverter para a reserva para a educação e formação cooperativas [al. a) do n. 2 do art. $97 .^{\circ}$ do CCoop].

A exigência da joia, no momento da admissão do cooperador, funcionará como:

i) um contributo a fundo perdido, reclamado a cada cooperador e motivado pelas despesas que o seu ingresso implica, as quais serão suportadas pela cooperativa (despesas de instalação de novos instrumentos de trabalho, despesas de manutenção acrescidas, e outras);

ii) uma forma de compensar, em parte, a contribuição dos anteriores cooperadores para o património comum da cooperativa ${ }^{38}$.

Claro que deveremos ter sempre presente o princípio cooperativo da adesão voluntária e livre, que impedirá o estabelecimento de condições de admissão excessivamente gravosas para os aspirantes a cooperadores. Efetivamente, o estabelecimento de montantes excessivos para a joia poderá constituir um obstáculo ao direito de admissão. Neste sentido, consideramos criticável que o novo Código Cooperativo não tenha consagrado um valor máximo para a joia, recuperando a solução prevista no Código de 1980 (art. 27. ), que consagrava um valor máximo do montante da joia, em função do capital social, que era então definido por uma percentagem sobre o capital social reportado ao último balanço aprovado.

À joia de admissão, o legislador acrescentou a possibilidade de a assembleia geral poder decidir outras formas de financiamento que não integram o capital social e que poderão assumir as modalidades de títulos de investimento e obrigações, já previstas no anterior Código (n. ${ }^{\circ} 3$ do art. $90 .^{\circ}$ ).

38 V., neste sentido, Fajardo García, La gestión económica de la cooperativa..., 5960; e Guido Bonfante, «Delle Imprese Cooperative: art. 2511-2545», em Commentario del cod. civ. Scialoja e Branca, ed. por Francesco Galgano (Bologna: Zanichelli Editore, 1999), 487-488. 
O regime jurídico dos títulos de investimento e das obrigações consta dos arts. $91 .^{\circ}$ a $95 .^{\circ}$.

\subsection{Consagração expressa do regime do aumento do capital social}

O Código Cooperativo de 1996 era omisso quanto ao regime de aumento do capital social. Ora, dadas as especificidades deste regime, sobretudo quando o aumento ocorre por via da incorporação de reservas, considerou-se relevante a criação de uma norma que previsse expressamente esta matéria.

Assim, quanto ao aumento do capital social estatutário, o n. 3 do art. $81 .^{\circ}$ consagra, expressamente, que este poderá ocorrer por duas vias: por deliberação da assembleia geral, mediante proposta do órgão de administração, com a emissão de novos títulos de capital a subscrever pelos membros; ou por incorporação de reservas não obrigatórias e reservas cuja dotação não resulte de benefícios provenientes de operações com terceiros.

Torna-se, deste modo, claro que nas cooperativas, diversamente das sociedades comerciais, a reserva legal não poderá ser utilizada para incorporação no capital, assim como as reservas constituídas com lucros provenientes de operações com terceiros.

Efetivamente, nas cooperativas, o aumento de capital por incorporação de reservas só poderá ser feito utilizando reservas não obrigatórias e cuja dotação não resulte de benefícios provenientes de operações com terceiros. Em apoio da nossa opinião, invocamos, desde logo, o art. 99. ${ }^{\circ}$ do CCoop, o qual estabelece a irrepartibilidade, pelos cooperadores, quer das reservas obrigatórias quer das reservas que resultem de benefícios provenientes de operações com terceiros. Constata-se que, se ocorresse um aumento de capital por incorporação de alguma dessas reservas, os cooperadores ficariam ou com mais títulos de capital ou com os mesmos títulos, mas de superior valor nominal. Ora, o cooperador que se retira da cooperativa (por demissão ou exclusão) terá direito ao «montante dos títulos de capital realizados segundo o seu valor nominal» (arts. $24 .^{\circ}$ e $26 .^{\circ}$ do CCoop). Torna-se, deste modo, evidente que um eventual aumento do capital social por incorporação de reservas obrigatórias, implicaria uma violação do disposto no art. $99 .^{\circ}$ e ainda do art. $114 .^{\circ}$, ambos do CCoop, consagrando este último preceito a regra da devolução desinteressada das reservas da cooperativa dissolvida. Acresce que, mesmo não tendo em conta essas regras, não poderemos esquecer que a reserva legal tem um preciso destino fixado na lei, o qual não 
contempla a possibilidade de poder ser integrada no capital social39, como veremos.

Já quanto às reservas estatutárias (n. 1 do art. $98 .^{\circ}$ do CCoop), entendemos que poderão ser utilizadas nesta modalidade de aumento de capital, desde que a deliberação de aumento de capital por incorporação das reservas valha também como deliberação de alteração estatutária. Também as reservas criadas por deliberação da assembleia geral, nos termos do n. ${ }^{\circ} 2$ do art. $98 .^{\circ}$ do CCoop, poderão ser utilizadas para aumento de capital por incorporação de reservas. Convém, todavia, não esquecer que estas reservas não obrigatórias são compostas por excedentes provenientes de operações com cooperadores. Sendo assim, em caso de aumento de capital por incorporação de tais reservas, só poderão participar nesse aumento os cooperadores que tenham contribuído para tais excedentes e na exata medida dessa contribuição, pelo que, em nome da certeza e segurança jurídicas, dever-se-ia ter consagrado legalmente esta limitação.

\subsection{Maior clarificação em matéria de responsabilidade}

O regime de responsabilidade dos cooperadores pelas dívidas da cooperativa aparece previsto em duas normas do novo Código: no art. $23 .^{\circ}$, inserido no Capítulo III relativo aos "Membros», e que reproduz a redação do art. $35^{\circ}$ do Código Cooperativo de 1996; e no art. $80 .^{\circ}$, inserido no capítulo relativo ao "Regime económico».

$\mathrm{O}$ art. $80 .^{\circ}$ tem a virtualidade de clarificar as mensagens normativas constantes do art. $233^{\circ}$. Assim, em matéria de responsabilidade da cooperativa e dos cooperadores perante os credores da cooperativa, a norma começa por enunciar a regra de que só o património da cooperativa responderá perante os credores pelas dívidas daquela, pelo que cada cooperador limita a sua responsabilidade ao montante do capital social subscrito, sem prejuízo de cláusula estatutária em sentido diverso. Finalmente, esclarece-se que, quando o contrato estipule a responsabilidade de cooperadores por dívidas da cooperativa, ela é subsidiária em relação à cooperativa e solidária entre os cooperadores responsáveis.

Refira-se que nem todo o património da cooperativa responde por dívidas desta.

39 V., neste sentido, Jorge Manuel Coutinho de Abreu, Da empresarialidade. As empresas no Direito (Coimbra: Almedina, 1999), 164 e ss.. 
Tal como destacaremos mais adiante, o novo Código Cooperativo consagrou que os bens afetados à reserva de educação e formação cooperativas, por fidelidade à sua vocação legal, só responderão pelo pagamento das dívidas contraídas na atividade a que está adstrita esta reserva e não pelas restantes dívidas da cooperativa ( $n .^{\circ} 7$ do art. 97. ${ }^{\circ}$ ).

Sublinhe-se, ainda, que estas normas se reportam a perdas da cooperativa e não a perdas imputáveis ao cooperador, porque resultantes da sua participação na atividade da cooperativa. Relembremos que, nas cooperativas, o cooperador não estará apenas sujeitado à obrigação de entrada para o capital da cooperativa, mas também à obrigação de participar na atividade da cooperativa [al. c) do n. ${ }^{\circ} 2$ do art. $22 .{ }^{\circ}$ do CCoop]. O resultado económico desta participação do cooperador na atividade da cooperativa poderá ser positivo (gerando um excedente que poderá retornar ao cooperador) ou negativo (significando uma perda).

Do ponto de vista jurídico ou patrimonial, estas perdas, que têm a sua origem no intercâmbio de prestações entre a cooperativa e os cooperadores, não são perdas da cooperativa, mas sim perdas do cooperador. Enquanto a responsabilidade externa (responsabilidade por dívidas) se reporta a compromissos assumidos pela cooperativa perante terceiros, a responsabilidade por perdas do cooperador reportase a uma atividade interna que a cooperativa desenvolve com os seus cooperadores - a já referida atividade cooperativizada - que é uma atividade económica que nasce de uma relação jurídica específica (a relação cooperativa ou mutualista) ${ }^{40}$.

Daí que estas perdas, que tiveram a sua origem no exercício de uma atividade realizada por conta do cooperador, devam ser imputadas aos próprios cooperadores, proporcionalmente à sua participação nessa mesma atividade ${ }^{41}$. É neste sentido que parece apontar o n. ${ }^{\circ} 5$ do art. $96 .^{\circ}$ do CCoop.

Diversamente, as perdas produzidas nas operações com terceiros e todas as demais perdas serão perdas da cooperativa, devendo ser su-

40 V., neste sentido, Carlos Vargas Vasserot, «Posición del socio», em Pérdidas, disolución y concurso en sociedades cooperativas, ed. por Juan Bataller Grau (Madrid: Marcial Pons, 2012), 165 e ss..

41 V., sobre esta questão, Fajardo García, La gestión económica de la cooperativa...., 183e ss.; Anxo Tato Plaza, A Lei de Cooperativas e a sua incidência nas Cooperativas de Ensino (Pontevedra: Unión de Cooperativas do Ensino de traballo asociado de Galicia, 1999), 72-74; e Manuel Paniagua Zurera, «Determinación y aplicación de resultados», em Tratado de Derecho de Cooperativas, Tomo I, dir. por Juan Ignacio Peinado Garcia; coord. por Trinidad Vázquez Ruano (Valencia: Tirant Lo Blanch, 2013), 686-707. 
portadas exclusivamente pelo património desta (arts. $23 .^{\circ}$ e $80 .^{\circ}$ do (Coop), tal como foi destacado ${ }^{42}$.

\subsection{Novas soluções normativas quanto às reservas cooperativas}

\subsubsection{Reserva LEGAL}

Em matéria de reserva legal, mantém-se a regra de que esta se destina, em exclusivo, à cobertura de eventuais perdas de exercício $\left(n{ }^{\circ} 1\right.$ do art. $96 .^{\circ}$ do (Coop), regra esta que evidencia a única finalidade da figura da reserva legal nas cooperativas: a de funcionar como primeira linha de defesa do capital social, evitando que as perdas decorrentes da atividade empresarial da cooperativa incidam diretamente sobre o capital social e determinem a sua redução. De facto, existindo a reserva legal, essas perdas serão cobertas, em primeira linha, pelos bens que no ativo the correspondem.

No novo Código Cooperativo, para que a reserva legal desempenhe adequadamente a sua função de defesa do capital social, introduziu-se um preceito que clarifica que ela só poderá ser utilizada para cobrir: a parte do prejuízo do exercício que não possa ser coberto pela utilização de outras reservas; ou a parte dos prejuízos transitados do exercício anterior que não possa ser coberta pelo resultado do exercício nem pela utilização de outras reservas [als. a) e b) do n. ${ }^{\circ} 4$ do art. $96 .^{\circ}$ ].

Não era este o regime que resultava do art. $69 .^{\circ}$ do Código Cooperativo de 1996. A redação dos n.os 1 e 4 daquele preceito permitia que as perdas fossem imputadas, em primeiro lugar e integralmente, à reserva legal, em vez de - como seria mais adequado, atendendo à função garantística desempenhada por tal reserva - ser feita, em primeiro lugar, aos fundos de reservas livres, se existirem, admitindo-se a imputação à reserva legal apenas com carácter subsidiário e mediante a fixação de limites, tal como resulta do atual regime.

Deveria, no entanto, o legislador ter expressamente previsto no novo Código que estas perdas, cobertas pela reserva legal, seriam perdas da cooperativa, excluindo-se as perdas imputáveis ao cooperador,

42 A jurisprudência portuguesa já se pronunciou sobre esta distinção no Acórdão do Tribunal da Relação de Lisboa de 11 de novembro de 2008 [Processo n. ${ }^{\circ}$ 6462/2008-1 (Relator: Rijo Ferreira), ITIJ —Bases Jurídico-documentais- http://www.dgsi.pt]. Ver, sobre este Acórdão, Deolinda A. Meira, "O regime de imputação de perdas na cooperativa (anotação ao Acórdão do Tribunal da Relação de Lisboa de 11 de Novembro de 2008)», Cooperativismo e Economía Social, n. ${ }^{\circ} 31$ (2008/2009): 279-284. 
porque resultantes da sua participação na atividade da cooperativa, como vimos.

Esta diferenciação é fundamental tendo em conta que, no n. ${ }^{\circ} 5$ do art. $96 .^{\circ}$ do CCoop, se dispôs que, caso a reserva legal não seja suficiente para cobrir os «prejuízos do exercício», os cooperadores poderão ser chamados, mediante deliberação da assembleia geral, a repor a diferença, proporcionalmente às operações realizadas por cada um deles com a cooperativa, reconstituindo-se a reserva até ao nível anterior em que se encontrava antes da sua utilização para a cobertura destas perdas.

Esta norma, que transitou do anterior Código Cooperativo, merecenos as seguintes considerações.

O legislador não se estará a referir a perdas da cooperativa, pois, quanto a estas, funciona a regra da responsabilidade limitada constante dos arts. $23 .^{\circ}$ e $80 .^{\circ}$ do CCoop, nos termos da qual o membro (cooperador ou investidor) não responde por perdas da cooperativa, pelas quais responde apenas o património desta. Mas também se pode questionar se o legislador se estará a referir a perdas imputáveis ao cooperador. Parece, efetivamente, que o texto da norma aponta nesse sentido, pois o legislador afirma que os cooperadores poderão ser chamados a repor a diferença «proporcionalmente às operações realizadas por cada um deles». No entanto, haverá que ter em conta que a reserva legal não se destina a cobrir perdas imputáveis ao cooperador, mas apenas perdas da cooperativa.

Quanto à constituição da reserva, mantém-se a regra segundo a qual esta deixará de ser obrigatória a partir do momento em que atinja «um montante igual ao máximo do capital social atingido pela cooperativa», acrescentando-se «no exercício» (n. 3 do art. $96 .^{\circ}$ do (Coop). Este montante, estabelecido pelo legislador cooperativo português — «um montante igual ao máximo do capital social atingido pela cooperativa no exercício»-, será um montante mínimo, no sentido de que os estatutos poderão estipular um montante superior, mas nunca inferior. O legislador não emprega a expressão «limite máximo», limitando-se a dizer que as reversões deixarão de ser obrigatórias «desde que», ou seja, a partir do momento em que a reserva atinja aquele montante.

\subsubsection{RESERVA DE EDUCAÇÃO E FORMAÇÃO COOPERATIVAS}

Quanto à reserva de educação e formação cooperativas, regulada pelo art. 97. ${ }^{\circ}$ do CCoop, mantém-se a obrigatoriedade da sua constituição. 
Funda-se, tal reserva, no princípio cooperativo da educação, formação e informação, o qual realça a obrigação de as cooperativas, na sua atividade, assegurarem a educação e formação, quer dos seus membros, quer dos titulares dos seus órgãos eleitos, quer dos seus administradores, quer dos seus trabalhadores. Além disso, este princípio abrange o dever de informar o público em geral, visando sensibilizá-lo para a natureza e vantagens da cooperação (art. 3. ${ }^{\circ}$ do CCoop).

A constituição deste tipo de reserva, com esta finalidade, significa que a cooperativa é não só uma organização económica, mas também uma organização com finalidades pedagógicas e sociais. Este fundo de reserva destinar-se-á, por isso, a custear atividades que ultrapassam a satisfação dos interesses puramente individuais dos seus membros, atividades que, não sendo propriamente económicas, poderão produzir, direta ou indiretamente, imediata ou diferidamente, efeitos de alcance económico, quer para a cooperativa, quer para a comunidade onde esta se insere.

De facto, a educação e formação dirigidas à qualificação profissional dos cooperadores, dos membros dos órgãos de administração e fiscalização, e dos trabalhadores contribuirão para a melhor compreensão dos modelos de governação e da estrutura financeira da cooperativa, potenciando a profissionalização da gestão e induzindo os cooperadores a participar ativamente na sua cooperativa, a deliberar corretamente nas assembleias, a eleger conscientemente os seus órgãos e a controlar a sua atuação. Além disso, a educação e informação cooperativas ao direcionarem-se ao público em geral — de modo a sensibilizá-lo quanto às especificidades do modelo cooperativo, quanto à filosofia e ideais que prossegue- fomentarão novas adesões e, sobretudo, adesões conscientes.

Assim, em coerência com as finalidades desta reserva, o legislador consagrou expressamente, no.$^{\circ} 3$ do art. $97 .{ }^{\circ}$, que esta reserva não responderá pelas dívidas da cooperativa perante terceiros, mas apenas pelas obrigações contraídas no âmbito da atividade a que está adstrita. Parece-nos acertada esta solução legislativa, pois, diversamente de outros ordenamentos, na legislação cooperativa portuguesa esta reserva nunca foi configurada como um fundo especial, constituído em património autónomo, mas apenas como uma conta, em sentido contabilístico, de capitais próprios.

\subsubsection{A IRREPARTIBILIDADE DAS RESERVAS (OBRIGATÓRIAS OU OUTRAS)}

O novo Código Cooperativo mantém a regra de que estas reservas obrigatórias (reserva legal e reserva de educação e formação 
cooperativas), bem como as reservas constituídas com resultados provenientes de operações com terceiros, serão insuscetíveis de qualquer tipo de repartição entre os membros cooperadores e investidores (art. 99. ${ }^{\circ}$ do CCoop).

No momento da liquidação do património da cooperativa, o art. $114 .^{\circ}$ dispôs, no seu n. ${ }^{\circ} 1$, que o montante da reserva legal —não afetado à cobertura das perdas de exercício e que não seja suscetível de aplicação diversa - «pode transitar com idêntica finalidade para a nova entidade cooperativa que se formar na sequência de fusão ou cisão da cooperativa em liquidação». Mas, nos termos do n. 3 do mesmo artigo do CCoop, estabeleceu-se que, «quando à cooperativa em liquidação não suceder nenhuma entidade cooperativa nova, a aplicação do saldo de reservas obrigatórias reverte para outra cooperativa, preferencialmente do mesmo município, a determinar pela federação ou confederação representativa da atividade principal da cooperativa». $\mathrm{O}$ n. ${ }^{\circ} 4$ foi ainda mais longe ao dispor que «às reservas constituídas nos termos do art. $98^{\circ}$ deste Código é aplicável, em matéria de liquidação e no caso de os estatutos nada disporem, o estabelecido nos números 2 e 3 deste artigo», o que significa que este regime poderá abranger, igualmente, as reservas livres, caso os estatutos sejam omissos.

Esta impossibilidade de distribuir o património residual, em caso de liquidação, deriva, desde logo, da função social que a cooperativa é chamada a cumprir e que implica que o seu destino, após a liquidação, seja a promoção do cooperativismo (o chamado Princípio da distribuição desinteressada) ${ }^{43}$.

Acresce que a eventual distribuição das reservas entre os cooperadores seria incompatível com o Princípio da adesão voluntária e livre. De facto, este princípio só se poderia praticar nos casos em que todos os membros da cooperativa renunciassem a uma parte dos excedentes líquidos do ativo. De contrário, os cooperadores que permanecessem na cooperativa até ao momento da liquidação seriam os únicos a beneficiar das reservas obrigatórias geradas com o esforço dos cooperadores que entretanto saíram da cooperativa. Mesmo no pressuposto de que nenhum cooperador se tenha demitido da cooperativa até ao momento da liquidação, qualquer distribuição destas reservas obrigatórias pelos cooperadores, na ausência de uma contabilidade analítica que evidenciasse o contributo de cada um deles para a formação destas reservas, causaria prejuízos aos cooperadores fundado-

43 Para uma análise desenvolvida deste princípio, v. María Luisa Llobregat Hurtado, Mutualidad y empresas cooperativas (Barcelona: Bosch, 1990), 374 e ss.. 
res relativamente àqueles que ingressaram em momento posterior na cooperativa. Daí que, da mesma maneira que os cooperadores não disporão, no momento em que se demitirem da cooperativa, do direito de reclamar uma quota-parte das reservas obrigatórias, haverá da mesma forma que impedir, chegada a fase da dissolução da cooperativa, a repartição entre aqueles do ativo líquido desta última. Neste contexto, o regime da irrepartibilidade permitirá evitar demissões especulativas.

Um outro argumento contra a possibilidade de repartição assenta na particular natureza destas reservas e, sobretudo, no facto de que estas são integradas, igualmente, por resultados provenientes de operações com terceiros, que se fossem distribuídos entre os cooperadores constituiriam um dividendo, pondo em causa o escopo não lucrativo da cooperativa.

A manutenção do regime da irrepartibilidade permite, ainda, atenuar os efeitos da variabilidade do capital social e incrementar as garantias face aos credores ${ }^{44}$.

3.9. O regime jurídico da determinação e distribuição de resultados: uma oportunidade perdida

A problemática da determinação e distribuição dos resultados continua a ser tratada de forma incipiente no novo Código Cooperativo, não obstante esta matéria constituir um pronto nevrálgico do regime económico das cooperativas.

Nas cooperativas são identificáveis três tipos principais de resultados:

- os resultados cooperativos, designados de excedentes (quando positivos) ou de perdas (quando negativos), correspondentes aos resultados provenientes da atividade económica desenvolvida entre a cooperativa e os seus membros (atividade cooperativizada);

- os resultados extracooperativos (positivos ou negativos) correspondentes aos resultados provenientes das operações com terceiros;

- e os resultados extraordinários (positivos ou negativos) provenientes de atividade alheia ao fim social da cooperativa ${ }^{45}$.

44 Sobre estes argumentos, v. Llobregat Hurtado, Mutualidad..., 379-381; e Chapter 3 Section 3.4, Draft Principles of European Cooperative Law..., 80 e ss..

45 Esta distinção está expressamente prevista na legislação cooperativa espanhola (v.g. art. 57. ${ }^{\circ}$ da Ley Estatal de Cooperativas - Ley 27/1999, de 16 de julio). V., sobre 
Esta distinção não está expressamente consagrada no novo Código Cooperativo ${ }^{46}$.

O regime de distribuição dos resultados previsto no novo Código merece as seguintes considerações.

Quanto aos resultados cooperativos, o legislador, na linha do anterior Código, limita-se a afirmar que os excedentes poderão retornar aos cooperadores (n. ${ }^{\circ} 1$ do art. $1000^{\circ}$ do CCoop), sem enunciar o critério que regula tal retorno, omissão que nos parece criticável.

Dada a participação económica dos membros cooperadores na atividade da cooperativa, a distribuição do retorno entre os cooperadores será feita em função e proporcionalmente às atividades ou operações efetuadas com a cooperativa de que são membros (valor das compras ou serviços consumidos ou prestados, no caso das cooperativas de consumo ou de serviços; valor das transações efetuadas ou produtos entregues, no caso das cooperativas agrícolas ou de comercialização), ou em função e proporcionalmente ao trabalho de cada membro (como é o caso das cooperativas de trabalho, nas quais na distribuição do excedente gerado pelos membros deverão ser deduzidos os levantamentos já recebidos «por conta dos mesmos») ${ }^{47}$.

No entanto, para além da orientação genérica consagrada no art. 3. ${ }^{\circ}$ do CCoop, no sentido de uma repartição dos excedentes em «benefício dos membros na proporção das suas transações com a cooperativa», quando se transcreve o enunciado do princípio cooperativo da participação económica dos membros, continuamos a não encontrar no Código Cooperativo qualquer critério substancial explícito que regule a distribuição dos excedentes ${ }^{48}$.

esta distinção, Fajardo García, La gestión económica de la cooperativa..., 120 e ss.; e Paniagua Zurera, "Determinación y aplicación de resultados», 659-686. Esta distinção foi também adotada no Draft Principles of European Cooperative Law..., 68 e ss..

46 Reclamando a necessidade de esta distinção constar expressamente da legislação cooperativa, v. Meira e Ramos, Governação..., 151 e ss..

47 V. Sobre esta questão, Hans-H Münkner, Co-operative Principles and Co-operative Law, 2nd, revised edition (Zurich: Lit Verlag GmbH \& Co. KG Wien, 2015), 147 e SS..

48 Na legislação aplicável aos diferentes ramos, também não encontrámos qualquer critério explícito de repartição, mas meras orientações genéricas. Assim, quanto às cooperativas culturais (Decreto-Lei n. ${ }^{\circ} 313 / 81$, de 19 de Novembro), dispõe-se, no seu art. 8. $^{\circ}$, que aquela distribuição será «proporcional ao trabalho de cada membro» e que deverá obedecer "aos critérios definidos nos estatutos ou regulamentos internos». Quanto às cooperativas de produção operária (Decreto-Lei n. ${ }^{\circ}$ 309/81, de 16 de Novembro), o art. 9. ${ }^{\circ}$ estabelece que, após a determinação dos excedentes, se deduzirão "os levantamentos dos membros recebidos por conta dos mesmos». Finalmente, o diploma que regula as cooperativas de serviços (Decreto-Lei $n .^{\circ} 323 / 81$, de 4 de Dezembro), es- 
Uma percentagem do excedente de exercício, resultante das operações com os cooperadores, reverterá para a reserva legal [n. 2 do art. $96 .^{\circ}$ do CCoop] e para a reserva para educação e formação cooperativas [al. b) do n. 2 do art. $97 .^{\circ}$ do CCoop], assim como para o eventual pagamento de juros pelos títulos de capital (n. ${ }^{\circ} 1$ do art. $100 .^{\circ}$ do (Coop).

Só depois de efetuadas estas reversões e pagamentos se estará em condições de apurar o retorno (n. ${ }^{\circ} 1$ do art. $100 .^{\circ}$ do CCoop).

O legislador continua a impedir, no novo Código, a distribuição de excedentes quando e na medida em que forem necessários para cobrir prejuízos transitados ou para reconstituir a reserva legal $\left(n .^{\circ} 2\right.$ do art. $1000^{\circ}$ do $(\text { Coop })^{49}$.

O direito ao retorno dos excedentes continua a poder ser derrogado por deliberação da assembleia geral [al. f) do art. 38. ${ }^{\circ}$ do CCoop], pelo que não existe um direito subjetivo ao retorno ${ }^{50}$.

Quanto aos resultados provenientes de operações com terceiros (que o legislador continua inapropriadamente a designar de excedentes), mantém-se a impossibilidade de que estes possam ser repartidos pelos membros cooperadores (n. 1 do art. $100 .^{\circ}$ do CCoop), solução que nos parece a mais acertada, tendo em conta as especificidades das cooperativas.

De facto, o n. ${ }^{\circ} 2$ do art. $2{ }^{\circ}$ do CCoop consagra, na linha do Código anterior, a possibilidade de as cooperativas, na prossecução dos seus objetivos, poderem «realizar operações com terceiros, sem prejuízo de eventuais limites fixados pelas leis próprias de cada ramo». Ainda que a lei não defina o que se deve entender por «terceiros», parece ser doutrina assente que, na esteira dos ensinamentos de Rui Namorado, «terceiros, de um ponto de vista cooperativo, são todos aqueles que mantenham com uma cooperativa relações que se enquadrem na prossecução do seu objeto principal, como se fossem seus membros embora de facto

tipula, no seu art. 9. ${ }^{\circ}$, que a distribuição dos excedentes, nas cooperativas de prestação de serviços, será feita «proporcionalmente ao trabalho de cada membro, segundo critérios definidos nos estatutos e/ou regulamentos internos da cooperativa, nos termos do art. $73 .^{\circ}$ do Código Cooperativo, deduzindo-se após a sua determinação, os levantamentos dos membros recebidos por conta dos mesmos».

49 Para uma análise desenvolvida desta questão, v. Deolinda A. Meira, «Revisitando o problema da distinção entre excedente cooperativo e lucro societário», em /l Congresso Direito das Sociedades em Revista (Coimbra: Almedina, 2012), 353-374.

50 Nas cooperativas de solidariedade social (art. 7. ${ }^{\circ}$ do Decreto-Lei n. ${ }^{\circ} 7 / 98$, de 15 de janeiro) e de habitação (art. $15 .^{\circ}$ do Decreto-Lei n. ${ }^{\circ}$ 502/99, de 19 de novembro) impede-se a distribuição de excedentes pelos membros, o que implica que todos os excedentes revertam, obrigatoriamente, para reservas. 
não o sejam ${ }^{51}$. Tal significa que as atividades com terceiros, de que fala o legislador, se reportarão a atividades do mesmo tipo da atividade desenvolvida com os cooperadores, pelo que as operações com terceiros estão ainda compreendidas no objeto social da cooperativa ${ }^{52}$.

Admite-se, no n. 2 do art. $2 .^{\circ}$ do CCoop, que as operações com terceiros possam ser objeto de limitações na legislação setorial dos diferentes ramos do setor cooperativo. Ora, ainda que previstas expressamente no art. 9. ${ }^{\circ}$ do Decreto-Lei n. ${ }^{\circ}$ 523/99, de 10 de dezembro (cooperativas de comercialização), no art. $7 .^{\circ}$ do Decreto-Lei n. ${ }^{\circ} 313 / 81$, de 19 de novembro (cooperativas culturais), no art. $14 .^{\circ}$ do Decreto-Lei n. ${ }^{\circ}$ 502/99, de 19 de novembro (cooperativas de habitação e construção), no art. $6 .^{\circ}$ do Decreto-Lei n. ${ }^{\circ}$ 309/81, de 16 de novembro (cooperativas de produção operária), no art. $6 .^{\circ}$ do Decreto-Lei n. ${ }^{\circ} 323 / 81$, de 4 de dezembro (cooperativas de serviços) e no art. $24 .^{\circ}$, n. ${ }^{\circ} 2$ e 3 do Decreto-Lei n. ${ }^{\circ}$ 24/91, de 11 de janeiro (cooperativas de crédito agrícola), apenas esta última norma estabelece concretamente limites às operações de crédito com não associados (35\% do respetivo ativo líquido total, o qual poderá ser elevado para 50\%, mediante autorização do Banco de Portugal).

É nosso entendimento que, quando tais limites não estejam previstos na lei, caberá aos estatutos da cooperativa a previsão dos mesmos. Não esqueçamos que, em si mesmas, as operações com terceiros são estranhas à forma jurídica cooperativa, pelo que a não existência de limites, previstos estatutariamente, poderá pôr em causa o escopo mutualístico destas entidades. Neste contexto, deveria o legislador, na reforma, ter sido mais assertivo nesta matéria consagrando que tais limites serão obrigatoriamente fixados pelas leis próprias de cada ramo ou, na sua falta, pelos estatutos da cooperativa ${ }^{53}$.

É verdade que para preservar o escopo mutualístico —acautelando uma transformação camuflada de uma cooperativa em uma sociedade comercial54_ o legislador cooperativo continua a impedir que os re-

51 V. Rui Namorado, Cooperatividade e Direito Cooperativo. Estudos e Pareceres (Coimbra: Almedina, 2005), 184.

52 V. Meira, O regime económico das cooperativas..., 268 e ss..

53 V. Deolinda A. Meira, «As operações com terceiros no Direito Cooperativo Português (Comentário ao Acórdão do Supremo Tribunal de Justiça de 18 de Dezembro de 2007)», Revista de Ciências Empresariais e Jurídicas, n. 17 (2010), 93-111; e Fici, "The essential role of cooperative law», 54-156.

54 O novo Código Cooperativo manteve a proibição da transformação da cooperativa em sociedade comercial, dispondo, no seu art. 111. ${ }^{\circ}$, que "é nula a transformação de uma cooperativa em qualquer tipo de sociedade comercial, sendo também feridos de nulidade os atos que contrariem ou iludam esta proibição legal». 
sultados provenientes de operações com terceiros sejam repartidos entre os cooperadores, quer durante a vida da cooperativa, quer no momento da sua dissolução (n. 1 do art. $100 .^{\circ}$ e art. $114 .^{\circ}$ do CCoop), sendo transferidos integralmente para reservas irrepartíveis. O fundamento deste regime prende-se com o facto de os resultados gerados nas operações da cooperativa com terceiros serem lucros (objetivos); ainda que, por não serem distribuíveis pelos cooperadores, não se possa falar de escopo lucrativo, uma vez não há lucro subjetivo, ${ }^{55 / 56}$.

No entanto, e como já foi destacado, para além das operações com cooperadores e com terceiros, poderemos, ainda, identificar um terceiro tipo de operações, a que chamaremos de operações extraordinárias, porque situadas fora do objeto social da cooperativa ${ }^{57}$. Os resultados provenientes das operações extraordinárias também são lucros (objetivos), ficando sujeitos ao mesmo regime aplicável aos resultados provenientes de operações com terceiros. Todavia, não encontramos qualquer norma no novo Código que se referia expressamente a estes resultados.

Em suma, em matéria de determinação e distribuição de resultados, foi uma oportunidade perdida a não introdução de um preceito que consagrasse expressamente as diferentes tipologias de resultados que acabamos de enunciar ${ }^{58}$.

\section{Conclusões}

A reforma do regime económico das cooperativas não pode alhearse, por um lado, da lógica própria em que este assenta - a qual resulta das características específicas do objeto social cooperativo e da necessária obediência aos princípios cooperativos - e, por outro lado, da circunstância de a cooperativa carecer de um regime económico que lhe assegure a sua sustentabilidade e que lhe forneça os mecanismos necessários para ser eficiente no mercado.

55 V., sobre a distinção entre excedente e lucro na cooperativa, Isabel-Gemma Fajardo García, «Orientaciones y aplicaciones del principio de participación económica», CIRIEC-España, Revista Jurídica de Economía Social y Cooperativa, Monográfico, n. 27 (2015), 215 e ss..

56 V., neste sentido, Jorge Manuel Coutinho de Abreu, «Empresas sociais (nótulas de identificação)», Cooperativismo e Economia Social, n. ${ }^{\circ} 37$ (2015), 369-376.

57 V. Fajardo García, La gestión económica de la cooperativa..., 113 e ss..

58 Reconhecendo esta diversidade de resultados económicos nas cooperativas, v. Chapter 3, Section 3.6 e Section 3.7, Draft Principles of European Cooperative Law..., 68-69 e, mais adiante, 83-86. 
O legislador, na reforma do Código Cooperativo português, foi sensível a estas especificidades e preocupações.

Com vista a aumentar a sustentabilidade da cooperativa, o novo Código Cooperativo prevê, de forma inovadora, a figura dos membros investidores, mas para preservar os princípios cooperativos da gestão democrática e da autonomia e independência, sujeitou esta nova figura a apertados limites imperativos.

De modo a incentivar o empreendedorismo cooperativo e a diminuir os custos de contexto, o legislador reduziu o montante do capital social mínimo.

O novo Código continua a reconhecer a variabilidade do capital social como uma caraterística essencial da identidade cooperativa, mas, para atenuar os seus efeitos e conferir maior estabilidade ao capital social cooperativo, alargou o elenco dos limites estatutários ao exercício do direito ao reembolso, admitindo a possibilidade de estatutariamente se prever que o órgão de administração suspenda o reembolso quando, num exercício económico, o montante dos títulos de capital a reembolsar supere uma determinada percentagem do capital social que neles se estabeleça.

De forma a fortalecer a função de garantia do capital social, deixam de poder ser emitidos títulos de capital em contrapartida de contribuições de trabalho, sem prejuízo de a legislação aplicável a cada um dos ramos cooperativos poder exigir, para a aquisição da qualidade de cooperador, uma contribuição obrigatória de capital e de trabalho. Além disso, passa a proibir-se expressamente que os credores particulares do cooperador possam penhorar, para satisfação dos seus créditos, os títulos de capital de que o cooperador seja titular.

Não abdicando da identidade cooperativa, consagrou-se expressamente, num preceito autónomo, o regime do aumento do capital social cooperativo, dispondo que o aumento de capital por incorporação de reservas só poderá ser feito utilizando reservas não obrigatórias e cuja dotação não resulte de benefícios provenientes de operações com terceiros.

Em nome da certeza e segurança jurídicas, passou a regular-se expressamente os formalismo e prazo a observar para a transmissão dos títulos de capital e clarificou-se o regime de responsabilidade dos cooperadores pelas dívidas da cooperativa, bem como da posição do património da cooperativa perante os seus credores e perante os credores particulares do cooperador.

Acolheram-se novas soluções normativas quanto às reservas. Atendendo à função de garantia desempenhada pela reserva legal, consagrou-se que a imputação de perdas da cooperativa será feita, em pri- 
meiro lugar, às reservas livres, se existirem, admitindo-se a imputação à reserva legal apenas com carácter subsidiário. Quanto à reserva de educação e formação cooperativas, dispôs-se que esta reserva não responderá pelas dívidas da cooperativa perante terceiros, mas apenas pelas obrigações contraídas no âmbito da atividade a que está adstrita.

Em nome da preservação da identidade cooperativa, manteve-se a regra da irrepartibilidade das reservas obrigatórias e das reservas constituídas com resultados provenientes de operações com terceiros.

Todavia, algumas questões não ficaram completamente resolvidas na reforma. Seria preciso ir mais longe do que a tímida abordagem legal feita à problemática da determinação e distribuição dos resultados, consagrando expressamente as diferentes tipologias de resultados, positivos e negativos, que são identificáveis nas cooperativas, enunciando explicitamente os critérios de distribuição dos excedentes e pronunciando-se, de forma mais assertiva, quanto aos limites que legalmente ou estatutariamente se impõem às operações desenvolvidas com terceiros.

\section{Bibliografia}

ABREU, Jorge Manuel Coutinho de, 1999. Da empresarialidade. As empresas no Direito. Coimbra: Almedina.

—, 2015. «Empresas sociais (nótulas de identificação)», Cooperativismo e Economia Social, n. ${ }^{\circ}$ 37: 369-376.

ALVES, Adriano Campos, 2013. «Brazil». Em International Handbook of Cooperative Law, editado por Dante Cracogna, Antonio Fici e Hagen Henrÿ, 271-288. Heidelberg: Springer.

BIONE, Massimo, 1997. "Le categorie dei soci finanziatori». Em La Società Cooperative: aspetti civilistici e tributari, editado por Giorgio Schiano di Pepe e Fabio Graziano, II Diritto Tributario, coord. por Antonio Uckmar e Victor Uckmar, Serie I, Vol. LXXXIV 17-30. Padova: CEDAM.

BONFANTE, Guido, 1999. «Delle Imprese Cooperative: art. 2511-2545». Em Commentario del cod. civ. Scialoja e Branca, editado por Francesco Galgano. Bologna: Zanichelli Editore.

CAPO, Giovanni, 1999. "Le società cooperative e lo scopo mutualistico». Em Società Cooperative e Mutue Assicuratrici, editado por Amadeo Bassi, 27123. Torino: UTET.

CZACHORSKA-JONES, Barbara, Jay Gary FINKELSTEIN e Bahareh SAMSAMI, 2013. "United States». Em International Handbook of Cooperative Law, editado por Dante Cracogna, Antonio Fici e Hagen Henrÿ, 759-778. Heidelberg: Springer.

DOMINGUES, Paulo de Tarso, 2015. "Capital e património sociais. Lucros e re-

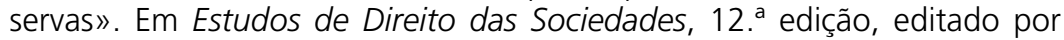
Jorge Manuel Coutinho de Abreu, 151-222. Coimbra: Almedina. 
FAJARDO GARCÍA, Isabel-Gemma, 1997. La gestión económica de la cooperativa: responsabilidad de los sócios. Madrid: Tecnos.

FAJARDO GARCÍA, Isabel-Gemma, Antonio FICl, Hagen HENRŸ, David HIEZ, Hans MÜNKNER e lan SNAITH, 2013. «El Nuevo grupo de studio en derecho cooperative europeo y el Proyecto «Los principios del derecho cooperativo europeo». CIRIEC-España, Revista Jurídica de Economía Social y Cooperativa, n. ${ }^{\circ} 24: 331-350$.

FAJARDO GARCÍA, Isabel-Gemma, 2015. "Orientaciones y aplicaciones del principio de participación económica». CIRIEC-España, Revista Jurídica de Economía Social y Cooperativa, Monográfico, n. ${ }^{\circ}$ 27: 205-241.

$\mathrm{FICl}$, Antonio, 2013. «Italy». Em International Handbook of Cooperative Law, editado por Dante Cracogna, Antonio Fici e Hagen Henrÿ, 479-501. Heidelberg: Springer.

$\mathrm{FICl}$, Antonio, 2014. "The essential role of cooperative law». The Dovenschmidt Quartely, International Review on Transitions in Corporate Life, Law and Governance, n. ${ }^{\circ}$ 4: 147-158.

GÓMEZ APARÍCIO, Pilar, 2000. «Algunas consideraciones sobre la remuneración del capital social en las sociedades cooperativas». REVESCO, n. ${ }^{\circ} 72$ : 87-97.

HENRŸ, Hagen, 2012. Guidelines for Cooperative Legislation. Genebra: International Labour Office.

HIEZ, David, 2013. Coopératives. Création, Organisation, Fonctionnement. Paris: Éditions Delmas.

LLOBREGAT HURTADO, María Luisa, 1990. Mutualidad y empresas cooperativas. Barcelona: Bosch.

—, 1999. «Régimen económico de las sociedades cooperativas en el marco de la nueva Ley General de Cooperativas de 16 de julio de 1999 (BOE de 17 de julio)». RdS, n. ${ }^{\circ}$ 13: 190-228.

MARTíN REYES, M. ${ }^{a}$ Ángeles e Eugenio OLMEDO PERALTA, 2013. «El capital social. Concepto y funciones». Em Tratado de Derecho de Cooperativas, Tomo I, dir. por Juan Ignacio Peinado Gracia; coord. por Trinidad Vásquez Ruano, 535-552. Valencia: Tirant Lo Blanch.

MEIRA, Deolinda A., 2008/2009. "O regime de imputação de perdas na cooperativa (anotação ao Acórdão do Tribunal da Relação de Lisboa de 11 de Novembro de 2008)». Cooperativismo e Economía Social, n. ${ }^{\circ}$ 31: 279-284.

-, 2009. O regime económico das cooperativas no Direito Português: o capital social. Porto: Vida Económica.

—, 2010. "As operações com terceiros no Direito Cooperativo Português (Comentário ao Acórdão do Supremo Tribunal de Justiça de 18 de Dezembro de 2007)». Revista de Ciências Empresariais e Jurídicas, n. ${ }^{\circ}$ 17: 93-111.

—, 2011. "As insuficiências do regime legal do capital social e das reservas na cooperativa». Em / Congresso Direito das Sociedades em Revista, 129-155. Coimbra: Almedina.

—, 2012. "Revisitando o problema da distinção entre excedente cooperativo e lucro societário». Em I/ Congresso Direito das Sociedades em Revista, 353374. Coimbra: Almedina. 
—, 2013. «A Lei de Bases da Economia Social Portuguesa: do projeto ao texto final». CIRIEC-España, Revista Jurídica de Economía Social y Cooperativa, n. ${ }^{\circ} 24: 21-52$.

- 2015. "Contributos legislativos para a criação de empresas cooperativas: a livre fixação do capital social». CIRIEC-España, Revista Jurídica de Economía Social y Cooperativa, n. ${ }^{\circ}$ 26: 35-37.

—, 2015. «O regime de distribuição de resultados nas cooperativas de crédito em Portugal. Uma análise crítica». Boletín de la Asociación Internacional de Derecho cooperativo, n. ${ }^{\circ}$ 49: 83-113. doi: 10.18543/ baidc-49-2015.

- e Ana Maria BANDEIRA, 2010. "A IAS 32 e os novos critérios de contabilização das entradas para o capital social das cooperativas. Uma análise contabilística e jurídica». Revista de Ciências Empresariais e Jurídicas, n. ${ }^{\circ} 16: 145-164$.

- e Maria Elisabete RAMOS, 2014. Governação e regime económico das cooperativas. Estado da arte e linhas de reforma. Porto: Vida Económica.

— e - 2015. «Os princípios cooperativos no contexto da reforma do Código Cooperativo português». CIRIEC-España, Revista Jurídica de Economía Social y Cooperativa, Monográfico, n. ${ }^{\circ} 27:$ 401-427.

MÜNKNER, Hans-H., 2015. Co-operative Principles and Co-operative Law. Zurich: Lit Verlag GmbH \& Co. KG Wien.

NAMORADO, Rui, 2005. Cooperatividade e Direito Cooperativo. Estudos e Pareceres. Coimbra: Almedina.

PANIAGUA ZURERA, Manuel, 2013. «Determinación y aplicación de resultados». Em Tratado de Derecho de Cooperativas, Tomo I, dir. por Juan Ignacio Peinado Gracia; coord. por Trinidad Vásquez Ruano, 659-707. Valencia: Tirant Lo Blanch.

PASTOR SEMPERE, María del Carmen, 2002. Los recursos propios en las sociedades cooperativas. Madrid: Editoriales de Derecho Reunidas, SA.

SNAITH, Ian, 2013. "United Kingdom». Em International Handbook of Cooperative Law, editado por Dante. Cracogna, Antonio Fici e Hagen Henrÿ, 735-757. Heidelberg: Springer.

STUDY GROUP ON EUROPEAN COOPERATIVE LAW (SGECOL), Draft Principles of European Cooperative Law (draft PECOL), May 2015, http://www. euricse.eu/wp-content/uploads/2015/04/PECOL-May-2015.pdf (última consulta em 29 de maio de 2016).

TATO PLAZA, Anxo, 1999. A Lei de Cooperativas e a sua incidência nas Cooperativas de Ensino. Pontevedra: Unión de Cooperativas do Ensino de traballo asociado de Galicia.

VARGAS VASSEROT, Carlos, 2011. "Aportaciones exigibles o no exigibles: ésa es la cuestión». CIRIEC-España, Revista Jurídica de Economía Social y Cooperativa, n. ${ }^{\circ} 22:$ 75-119.

-, 2012. "Posición del socio». Em Pérdidas, disolución y concurso en sociedades cooperativas, editado por Juan Bataller Grau, 165-191. Madrid: Marcial Pons. 
- 2006. La actividad cooperativizada y las relaciones de la Cooperativa con sus sócios y con terceros. Navarra: Editorial Thomson Aranzadi.

VIGUERA REVUELTA, Rodrigo, 2015. El derecho de reembolso en las sociedades cooperativas. Valencia: Tirant Lo Blanch.

ZOPINI, Andrea, Daniela BOGGIALI e Antonio RUOTOLO, 2005. «Coordinamento tra la disciplina dei soci sovventori e le norme sui soci finanziatori». Em Studi e materiali in tema di riforma delle Società Cooperative, Consiglio Nazionale del Notariato, Guiffrè Editore, 616-631. Milano: Consiglio Nazionale del Notariato, Guiffrè Editore. 


\section{Derechos de autor}

El Boletín de la Asociación Internacional de Derecho Cooperativo es una revista de acceso abierto lo que significa que es de libre acceso en su integridad inmediatamente después de la publicación de cada número. Se permite su lectura, la búsqueda, descarga, distribución y reutilización legal en cualquier tipo de soporte sólo para fines no comerciales y según lo previsto por la ley; sin la previa autorización de la Editorial (Universidad de Deusto) o el autor, siempre que la obra original sea debidamente citada (número, año, páginas y DOI si procede) y cualquier cambio en el original esté claramente indicado.

\section{Copyright}

The International Association of Cooperative Law Journal is an Open Access journal which means that it is free for full and immediate access, reading, search, download, distribution, and lawful reuse in any medium only for non-commercial purposes, without prior permission from the Publisher or the author; provided the original work is properly cited and any changes to the original are clearly indicated. 